\title{
STEPPES, SAVANNAHS, FORESTS AND PHYTODIVERSITY RESERVOIRS DURING THE PLEISTOCENE IN THE IBERIAN PENINSULA
}

\author{
Penélope González-Sampériza, Suzanne A.G. Leroyb, José S. Carriónc, \\ Santiago Fernándezc ${ }^{c}$ Mercedes García-Antón ${ }^{d}$, María José Gil-Garcíae, Paloma Uzquianof, \\ Blas Valero-Garcésa, Isabel Figueiralg \\ aPyrenean Institute of Ecology-CSIC, Av/ Montañana 1005, 50059 Zaragoza (Spain) pgonzal@ipe.csic.es \\ bInstitute for the Environment, Brunel University, Uxbridge (West London), Middlesex UB8 3PH (UK) \\ 'Botany Area, Faculty of Biology, University of Murcia, 30100 Murcia (Spain) \\ 'Department of Biology (Botany), Faculty of Sciences, Universidad Autónoma de Madrid, 28049 Cantoblanco, Madrid \\ (Spain) \\ eDepartment of Geology, University of Alcalá, 28871 Madrid (Spain) \\ fNational University of Distance Education (U.N.E.D.). Edificio Humanidades. Senda del Rey s/n, 28049 Madrid \\ (Spain) \\ gINRAP, DIR Méditerranée, 561 rue Etienne Lenoir, Km delta, 30900 Nîmes and CBAE (UMR 5059, \\ USTL/CNRS/EPHE), 163 rue A. Broussonet, 34090 Montpellier (France)
}

\section{Abstract}

A palaeobotanical analysis of the Pleistocene floras and vegetation in the Iberian Peninsula shows the existence of patched landscapes with Pinus woodlands, deciduous and mixed forests, parklands (savannah-like), shrublands, steppes and grasslands. Extinctions of Arctotertiary woody taxa are recorded during the Early and Middle Pleistocene, but glacial refugia facilitated the survival of a number of temperate, Mediterranean and Ibero-North African woody angiosperms. The responses of Iberian vegetation to climatic changes during the Pleistocene have been spatially and temporarily complex, including rapid changes of vegetation in parallel to orbital and suborbital variability, and situations of multi-centennial resilience or accommodation to climatic changes. Regional characteristics emerged as soon as for the Middle Pleistocene, if not earlier: Ericaceae in the Atlantic coast indicating wetter climate, thermo-mediterranean elements in the south as currently, and broad-leaf trees in the northeastern. Overall, steppe landscapes and open Pinus woodlands prevailed over many continental regions during the cold spells of the Late Pleistocene. The maintenance of a high phytodiversity during the glacials was linked to 
several refuge zones in the coastal shelves of the Mediterranean and intramountainous valleys. Northern Iberia, especially on coastal areas, was also patched with populations of tree species, and this is not only documented by palaeobotanical data (pollen, charcoal) but also postulated by phylogeographical models.

Key words: Pleistocene, Palynology, Anthracology, Iberian Peninsula, Vegetation Refugia 


\section{1.- Introduction}

Published material dealing with vegetational landscapes of the Iberian Pleistocene have considerably increased over the last few decades. This involves more studied sites, a broader time span, new long continuous sequences, the filling up of crucial geographic gaps, and a visible effort of bio-correlation. However, our knowledge of the Pleistocene vegetation is still incomplete, and a review of these gaps, together with a summary of the major developments is needed. The goal of this paper is therefore to critically revisite and synthetise the available palaeobotanical information, mainly in the form of pollen and charcoal records, but also plant megafossils and seeds (Fig. 1, Table 1). This information will be presented by periods (Early, Middle and Late Pleistocene) with the aim of illustrating the broad spectrum of vegetation changes in various parts of the Iberian Peninsula, characterised by different climatic influences, as well as the location and composition of glacial refugia for temperate and Mediterranean woody species.

A limitation to produce contending models of vegetation dynamics for the study period is the very small number of long, continuous palaeobotanical sequences available for the Iberian Peninsula. We are still dependent on the information derived from few sites such as Padul (Florschütz et al., 1971, Pons and Reille, 1988), Carihuela (Carrión et al., 1999, Fernández et al., 2007), and the marine ODP 976 site in the south (Combourieu-Nebout et al., 1999), and Area Longa in the north (Gómez-Orellana et al., 2007). To correlate these data with the number of fragmentary pollen sequences is challenging. At a first sight, regardless of the patchiness of the physical context, the general patterns of the Pleistocene European vegetation history are shared in the Iberian scene. However, there are peculiarities, especially related with the floristic composition and the spatial pathway of permanence of thermophilous floras during cold-arid periods. These patterns will be a topic of particular attention in this paper.

\section{2.- Present-day mosaics of climate and vegetation}


Strong climatic and geographic gradients and topographic contrasts have contributed to a marked physiographic heterogeneity in the Iberian Peninsula and Balearic Islands (Fig. 1). Owing to its relatively low latitude, this is one of the European regions that persisted mostly free of glaciated areas during the Pleistocene. Iberia is also one of the Mediterranean peninsulas with the highest floristic diversity and endemism (Castroviejo, 2002, Sainz-Ollero and Moreno, 2002). Many factors have contributed to this richness, but tectonic history including the existence of islands and episodic bridges with North Africa during the Late Tertiary, appear most relevant (RodríguezSánchez et al., 2008).

The orography of the Iberian Peninsula is characterized by mountain chains, which are aligned East-West and which determine a varied types of climates (Capel Molina, 1981) and habitat (Fig. 1). Current, and plausibly past vegetation distributions, were deeply marked by these transversal biological barriers that impeded a fluid latitudinal taxa migration in response to climatic oscillations. In the north, the Pyrenees, the Cantabrian Cordillera and the GalaicoLeoneses Mountains underline the most important limit between the Atlantic and the Mediterranean Iberia. These Atlantic regions are characterized by an important oceanic influence with high precipitation (more than $1000 \mathrm{~mm} / \mathrm{yr}$ and without summer drought) and cool-milder annual temperatures $\left(13^{\circ}\right.$ to $\left.15^{\circ} \mathrm{C}\right)$. The centre of the peninsula is also crossed by mountain ranges, mainly the Central System (Ayllón, Guadarrama, Gredos and Serra da Estrela), which divides the two plateaux (northern and southern "mesetas") that correspond to the Duero and Tajo river basins, respectively. Another important mountain chain is the Iberian System that runs from the North-West to the South-East and marks the limit between river basins that flow to the Atlantic Ocean or to the Mediterranean Sea. A strong continentality is derived from this orography. Central Iberia shows the typical summer drought of Mediterranean climates with strong thermic contrasts (lower than $6^{\circ} \mathrm{C}$ in winter and more than $26^{\circ} \mathrm{C}$ in summer), and including some semi-arid areas such as the North-East Ebro Basin, with $300 \mathrm{~mm}$ of annual 
precipitation. The southernmost Betic and Penibetic Mountain Systems have permitted an altitudinal scenario for species migrations during the Pleistocene (Carrión, 2002a). Coastal eastern and southern lowlands exhibit mild climates with severe summer drought and annual temperatures higher than $18^{\circ} \mathrm{C}$.

The geological map is puzzling (Vera, 2004), but overall, the Iberian Peninsula can be divided into a western, siliceous and an eastern, calcareous zone, with some material intrusions in between. Logically, this partitioning is critical for the vegetation distribution, and added to climate, they determines the biogeographical provinces within the Eurosiberian and Mediterranean regions (Rivas Martínez, 2007). The Eurosiberian Region comprises a narrow band from the eastern Pyrenees to Galicia and to the north-western slopes of Portugal, with a climate characterized by high annual precipitation without summer drought and a vegetation dominated by mesic forests with Quercus, Fagus, Tilia, Ulmus, Acer, and Fraxinus, sometimes mixed with Pinus sylvestris, Pinus uncinata and Abies alba at altitude. The Mediterranean Region occupies the rest of the Peninsula and the Balearic Islands and enjoys a generally warmer and drier climate characterized by summer drought (Capel Molina, 1981). The great extension of Mediterranean Iberia implies an important spatial variation related not only to the geology, but also to coastal (Atlantic or Mediterranean) or continental influences, and to altitudinal gradients, which condition the eventual occurrence/dominance of semi-deciduous or evergreen Quercus, Pinus and Juniperus formations (Fig. 1). Higher average temperatures allow the existence of a thermomediterranean belt in eastern and southern coastal areas with sclerophyllous forest-scrub that includes Quercus coccifera, Pistacia lentiscus, Ceratonia siliqua, Chamaerops humilis, Pinus halepensis, and $P$. pinea among other species. The mesomediterranean belt is often characterized by Quercus ilex and Quercus suber formations, and, at the supramediterranean belt, by semi-deciduous formations of Quercus faginea and Quercus pyrenaica, and coniferous forests with Pinus sylvestris, Pinus nigra, Pinus pinaster, and sporadically Juniperus thurifera are 
developed. Coniferous open woodlands can reach and be widespread along the highest elevation, the oromediterranean belt.

The aforementioned arid lands in the northeastern and southeastern of lberia are characterized by steppe formations with xerophytic Poaceae (such as Stipa and Lygeum), Asteraceae, Chenopodiaceae (such as Salsola and Suaeda) and even interesting biogeographical disjunctions such as Krascheninnikovia ceratoides, which testify to a larger distribution, fragmented after the desiccation of the Mediterranean Sea during the Messinian crisis (Pérez-Collazos and Catalán, 2007). The semi-arid southeastern is also characterized by Ibero-Maghrebian, xerothermic elements such as Periploca angustifolia, Withania frutescens, Maytenus senegalensis, Osyris quadripartita, and Tetraclinis articulata, among others (Carrión et al., 2009b). Finally, in the south-western, it is worth mentioning the presence of palaeotropical species like Prunus Iusitanica, Rhododendron ponticum, Laurus nobilis, Davalia canariensis and Psilotum nudum, among others, which may have persisted since the Tertiary or before, and contribute significantly to the floristic particularity of the region (Costa Tenorio et al., 1990, Blanco-Castro et al., 1997, García-Antón et al., 2002, Calleja et al., 2009).

\section{3.- Stratigraphy and main climatic trends}

The first glacial periods with open vegetation in Europe (Suc and Popescu, 2005) started at 2.589 Ma (pre-cyclostratigraphy: $2.4 \mathrm{Ma}$ ) at the Gauss-Matuyama transition across the marine isotopic stages (MIS) 100, 98, and 96 (Shackleton et al., 1995) (Fig. 2). This will be taken as the base of the Quaternary and the Pleistocene (Leigh Mascarielli, 2009). The preparation of these cold MIS is already seen in the earlier MIS 104 and 102. Two stages subdivide the Early Pleistocene: i) the Gelasian Stage, which starts at MIS 103, 20 ka after the Gauss/Matuyama boundary, with an astrochronological age of $2.589 \mathrm{Ma}$, and which has been ratified in 1996 (Rio et al., 1998); and ii) the Calabrian Stage at MIS 65 (only 25 ka before the top of the Olduvai Chron, with an 
astrochronological age of $1.795 \mathrm{Ma}$ ) up to the top of Jaramillo sub-chron at MIS 25 (at about 0.99 $\mathrm{Ma})$.

In 1996, the INQUA and International Commission of Stratigraphy (ICS) jointly proposed that the Early-Middle boundary of the Pleistocene should be at the Brunhes-Matuyama magnetic reversal boundary, at 0.781 ka (Fig. 2). However, this has not yet been ratified (Gibbard and van Kolfschoten, 2005). Head and Gibbard (2005) recommend the MIS 19 for this boundary, in which the Matuyama-Brunhes boundary occurs, even though this stage is not an exceptionally significant palaeoenvironmental event. The period covered by the Gelasian-Calabrian Stages (GCS) is delimited by the two shifts in astronomical forcing: from precession to obliquity at the Gauss-Matuyama (at 2.6 Ma), and from obliquity to eccentricity at the top of Jaramillo (at $0.9 \mathrm{Ma}$ ) (Fig. 2). The difference between the end of the Early Pleistocene and the end of the Calabrian covers a 200 ka-long period of transition between obliquity and eccentricity forcing. It is generally accepted that a first opening of the landscape would correlate to the Piacenzian-Gelasian transition and a second one to the final Calabrian / onset of the Middle Pleistocene. The Gelasian-Calabrian transition is not believed to correspond with any major environmental change (Cita et al., 2008).

The rest of the Pleistocene chronology is not so controversial, but it must be kept in mind that most of the more recent boundaries are actually not officially defined. In general, the Middle to Late Pleistocene limit is associated with the base of the Eemian period during the Marine Isotope Stage 5 (MIS 5).

In summary, the most significant change seems to be caused by the replacement of lowamplitude 41 ka obliquity forced climate cycles of the Early Pleistocene to, progressively, a highamplitude 100 ka rhythm of eccentricity-dominated cycles during the Middle and Late Pleistocene (Raymo et al., 2004, Clark et al., 2006, Lisiecki and Raymo, 2007). This change relates to a substantial increase of global ice volume and parallels a transition to a strongly non-linearly 
forced climate system, with a profound effect on the vegetation landscape of the northern hemisphere (Head and Gibbard, 2005). Interestingly, this may have a connection with the regional extinction of cold-intolerant vascular plants (Svenning, 2003, Postigo et al., 2009).

\section{4.- Iberian floras and vegetation during the Pleistocene}

Early to Middle Pleistocene records are scarce while Late Pleistocene sequences are more abundant. Josefa Menéndez-Amor (Madrid, Spain) and Frans Florschütz (Leiden, the Netherlands) conducted pioneer palynological work in many sites of Spain (e.g. Menéndez-Amor and Florschütz, 1959), whereas Villalta and Vicente (1972) produced the first publications on the analysis of fossil leaves. Since that time, palaeobotanical studies and scientists became more numerous. In Portugal, the first Quaternary palaeobotanical works (palynology included) were carried out by Teixeira (1943), followed by Andrade (1944). Their research was later compiled by Zbyszewski (1953). Quaternary palaeobotanical work became more frequent since the 1970s (e.g. Diniz, 1972) and a first data collection was produced by Mateus and Queiroz (1993). Pleistocene anthracological research is relatively recent (Figueiral, 1990, for NW Portugal, Ros Mora, 1987, for Catalonia, Badal, 1991, and Grau, 1990, for the Valencia region in the Levant, Rodríguez-Ariza, 1996, for Andalusia, Uzquiano, 1992a, for the Cantabrian region) but currently, charcoal analysis is a common method for palaeoecological reconstruction (Allué, 2002, CarriónMarco, 2005, Badal et al., 2008, Uzquiano, 2008).

\section{1.- The Early Pleistocene (2.6-0.8 Ma)}

Eight palaeobotanical Iberian sites of an Early Pleistocene age are discussed (Table 2). They have been selected either because of their extension in time or because they provide exceptional taxonomic resolution. The present level of information remains very patchy and involves some biases. Six of these sites are concentrated in north-eastern Spain (Garraf 1, Incarcal Crespià, 
Tres Pins, Bòbila Ordis, Molí Vell and Cal Guardiola; sites 104, 62, 72, 55, 66 and 56, respectively, in Fig. 1), and only one comes from the south (marine core ODP site 976, site 112 in Fig. 1). The remaining site comes from the central peninsula (Atapuerca, site 38 in Fig. 1). Another bias is in favour of low altitude sites, with the exception of Atapuerca (Table 2).

It is worth emphasizing that pollen records for this period have no analogs in the present vegetation both at the species composition and assembling levels (Fauquette et al., 1998a). Rather, similar, although not identical assemblages can be found in Asia and North America (Suc, 1980, Leroy, 1990, Roiron, 1992). The picture could also be somewhat inherited from the Pliocene, during which Fauquette et al. (1998a, 1998b) have suggested that temperature and precipitation were higher than currently in the interglacials and similar to the present in the glacial periods.

The Garraf 1 borehole record, offshore Barcelona (site 104 in Fig. 1), extends from the Late Miocene to the Early Pleistocene (Suc and Cravatte, 1982). The nineteen Pleistocene samples at the top of the core are largely dominated by conifers and Artemisia (Fig. 3). Other important arboreal taxa are Taxodiaceae and Quercus. In the underlying pollen zone, a coastal forest has been reconstructed, whose extent in the Early Pleistocene is reduced by the first glacial periods. These spectra have been correlated to MIS 108-98 (Suc and Popescu, 2005). Trends towards both cooling and aridification have been suggested (Fauquette et al., 1998a, 1998b). The northeastern site of Crespià (site 62 in Fig. 1), renowned for its rich mammal fauna, provides crucial palaeobotanical information through well-preserved leaf imprints (Villalta and Vicente, 1972). Four hundred specimens formed the basis for a new study of the two levels rich in leaves by Roiron $(1983,1992)$. Interglacial forests have been depicted with Quercus cerris, Carpinus suborientalis, Carya minor, Acer integerrimum, Zelkova crenata, Parrotia persica and Carpinus orientalis. This is largely a deciduous forest, but the assemblages include sub- 
xerophytic species (Carpinus orientalis, Quercus cerris and Acer monspessulanum). Following Roiron $(1983,1992)$, species identified are consistent with a Mediterranean type of climate.

Two pollen sequences at Tres Pins (site 72 in Fig. 1), south of Crespià, although nondated, illustrate a glacial period dominated by Pinus, Asteraceae and Poaceae followed by an interglacial phase with Carpinus betulus-t., deciduous Quercus, Carya and Ulmus-Zelkova (Leroy, 1987, 1997). The top of the core is affected by shallowing of the lake as indicated by the development of Cladium mariscus and Thelypteris palustris, and by soil formation with nonpolleniferous levels. The site of Bòbila Ordis (Fig. 4) is made of a succession of at least three lakes nested in each other and separated by faults and karstic collapses (Leroy, 2008). This site (site 55 in Fig. 1), has been studied by several generations of palynologists and yielded more than 250 samples (Elhaï, 1966, Geurts, 1977, Julià and Suc, 1980, Leroy, 2008). Lake 1, the oldest, is dated by palaeomagnetism (Løvlie and Leroy, 1995) and by micromammals (Leroy, 2008). It embraces at least one glacial-interglacial cycle. Lake 2 produced pollen assemblages typical of a glacial period: Pinus, Poaceae and Asteraceae (Leroy, 1988). In the sediment of Lake 3, large mammals bones have been found. Based on this and on the glacial and interglacial periods reconstructed by palynology, the Bòbila Ordis sequences have been correlated to MIS 36 to 33 (Elhaï, 1966, Geurts, 1977, Julià and Suc, 1980, Leroy, 1987). During the interglacials, a deciduous forest occurred, with deciduous Quercus, Ulmus, Pinus, Carpinus betulus, Carya and the Parrotia persica. The conifers such as hemlock or fir only developed at the end of the interglacials. The glacial periods are weakly developed, but the landscape opened up with the expansion of Pinus, Asteraceae, Poaceae, and eventually Artemisia. It has been suggested that Tres Pins is slightly older than Bòbila Ordis, on the basis of the occurrence of the ulteriorly extinct Pterocarya, Carya and Parrotia persica.

The site of Molí Vell (site 66 in Fig. 1), north of Rio Fluvià near Dosquers, was studied in outcrop, and twenty samples showed: i) a first phase of open landscape with Pinus and 
deciduous trees such as Quercus, Tilia, Ulmus, Carya and Corylus; ii) a second phase with increasingly forested landscape and development of deciduous forests especially with Quercus, Carya and Ostrya; and finally, iii) a slight re-opening of the vegetation, probably under cooler and wetter conditions, as suggested by decreasing Quercus and increasing Carya-Abies assemblages (Geurts, 1977, 1979, De Deckker et al., 1979). Geurts also published a very detailed analysis on the sublaminae of a varved unit from Molí Vell (De Deckker et al., 1979). Subannual pollen samples were analysed and showed the seasonal signal of successive plant blooming: Quercus in the beige layers which have been attributed to spring and Tilia and Pinus in grey layers linked to early summer.

Cal Guardiola (site 56 in Fig. 1), north of Barcelona, yielded a rich flora that came all from one chaotic debris flow, level D2, representing a snapshot of time somewhere between 1.2 and $0.8 \mathrm{Ma}$ (Postigo et al., 2007). A hundred pieces of wood were identified, including Acer aff. pseudoplatanus, deciduous Quercus, Aesculus hippocastanum, Ulmus, Acer campestre and Fraxinus angustifolia. Twenty-five pollen samples and two coprolites provided a palynoflora suggestive of a mixed forest with significant amounts of evergreen Quercus with Pinus and Cupressaceae. The mesocratic group is represented by deciduous Quercus, Viburnum opulus, Carya, Castanea and Juglans. Small but significant amounts of Mediterranean taxa are also recorded: Phillyrea, Pistacia, Cistus, Thymelaeaceae and Chamaerops-type.

Only a small part of the Atapuerca sequence (province of Burgos, site 38 in Fig. 1), below horizon TD8, reaches the Early Pleistocene. Hominid remains have been found in the underlying horizon TD6 and have been dated by luminescence and palaeomagnetism (Berger et al., 2008, Parès and Pérez-González, 1999). A first study of TD6, TD5 and TD4 (although only five, two and one samples were studied, respectively; Cattani et al., 1994, García-Antón, 1995, 1998) and first data of new TD6 (Burjachs, 2001) reveal similar results: an open Mediterranean woodland (evergreen and deciduous Quercus with Olea) with herbaceous taxa (Poaceae and 
Chenopodiaceae). Celtis, Castanea, Ceratonia, Carpinus t. betulus and Taxodiaceae are present in TD6. A more complete study is ongoing (Burjachs, pers. comm.).

The ODP site 976 in the Alboran Sea (site 112 in Fig. 1) yielded a 366 m long composite core (Combourieu-Nebout et al., 1999). A detailed analysis of the obliquity-forced MIS31 to 23 has become available recently (Joannin, 2007). Some difficulties for precise palaeoenvironmental reconstruction of Iberia are inherent to this marine sequence: 1) pollen sources are believed to be from both southern Spain and northern Africa; and 2) Pinus might be over-represented, as in all marine sequences. Several vegetation shifts are noticed, varying from prevailing mesothermic (such as Quercus and Ericaceae) to steppic phases (Artemisia and Ephedra). A mountain belt with Cedrus, Tsuga, Abies and Picea is also detected at altitude at the end of the interglacials. Cupressaceae is more abundant at the beginnings of interglacials. Asteraceae (especially liguliflorae), Caryophyllaceae and Poaceae are also well represented.

Some of the most famous failures to extract pollen from lake sequences should also be cited (Carrión et al., 2009): Baza-Orce, where at least five palynologists unsuccessfully worked with diverse lithological materials (Agustí and Julià, 1990, Gibert et al., 1988). From Mas Miquel quarry in Catalonia (site 65 in Fig. 1), dated by Early Pleistocene mammals, two attempts to analyse the pollen in twelve samples in lacustrine sediment failed as the results indicated poorly preserved pollen and pollution (Geurts, 1977, 1979, Leroy, 1990). The Incarcal quarry at Crespià (site 62 in Fig. 1), with its leaves and mammals bones, has also delivered only unsatisfactory results (Geurts, 1977, 1979, Suc, 1980, Leroy, 1990). Moreover, it is not uncommon that Early Pleistocene sites are poorly dated. Some longer sequences in lberia with steps of vegetation changes have been correlated to the Piacenzian-Gelasian transition or to the Calabrian-Ionian transition with the danger of the "suck in" phenomenon (Baillie, 1991). The first phase of landscape opening was clearly shown in the Garraf 1 core (site 104 in Fig. 1; Suc and Cravatte, 1982), and the second step (in the transitional period between the end of the Calabrian and the 
beginning of the Middle Pleistocene) is perhaps recorded in the ODP 976 marine core (site 112 in Fig. 1) with the pronounced decrease of Abies in the coniferous forests (Combourieu-Nebout et al., 1999).

In conclusion, vegetational landscapes during the Late Pliocene-Early Pleistocene, were characteristically diverse. Pinus was quite an abundant and persistent element. In areas such as northeastern Catalonia, dense forests developed during the interglacials. Glacial periods are brief but the landscape opened up with the development of Pinus, Poaceae and Asteraceae liguliflorae (especially) and some tubuliflorae (but not so much Artemisia).

\section{2.- The Middle Pleistocene (800-125 ka)}

The scarcity of palaeobotanical data attributed to the Middle Pleistocene in Iberia, in respect to other Mediterranean regions from southern Europe such as Greece, Italy or France (which reveal even longer sedimentary records), is worth mentioning. The available information corresponds to fragmentary sequences, with a very low number of studied samples, which are geographically and chronologically discontinuous coverage (Table 1). In addition, most of the sites are not well dated and assigned only generally to glacial (Riss) or interglacial (Mindel-Riss) conditions. Exceptions include Atapuerca (site 38 in Fig. 1) in northern Spain (García-Antón and SainzOllero, 1991, Cattani et al., 1994, García-Antón, 1995, 1998, Burjachs, 2001), and Morgandinho (site 35 in Fig. 1) in the Portuguese Algarve (Antunes et al., 1986), which show palaeoflora data for the end of the Early Pleistocene and the beginning of the Middle Pleistocene.

During the last few years several palynological studies have been made in marine cores from the Atlantic coast (Desprat et al., 2005, 2006, Roucoux et al., 2006, 2007) and the Mediterranean Sea (Combourieu-Nebout et al., 1999); but the correlation between marine and continental data is rather difficult due to the differences in source areas of pollen rain and the uncertainties of chronological models. The Morgandinho site (site 35 in Fig. 1) spans the end of 
the Early Pleistocene to the beginning of the Middle Pleistocene (Antunes et al., 1986). Only two samples show a landscape dominated by conifers, mainly Pinus that reaches $70 \%$, but also Picea $(3 \%)$ and Keteeleria (8\%), as a signal of its persistence in the region during this period. The interpretation of the flora allowed the authors to locate the record at the limit between the Early and the Middle Pleistocene, perhaps between MIS 20 and 17. In the rest of the Portuguese sites (Table 1) attributed imprecisely to the Mindel-Riss interglacial or the Riss glaciations (Andrade, 1944, Teixeira, 1943, Zbyzewski, 1958), the presence of Pinus, Quercus, Betula and Ericaceae is noticeable.

In northeastern Iberia, further palaeoenvironmental data are recorded around Olot (Girona). Geurts (1979) studied five samples from a Middle Pleistocene sequence in Mas Grill (site 64 in Fig. 1) showing a climatically mild, forested environment dominated by Pinus, Quercus and Alnus. The presence of Fagus, Ostrya, Juglans and Carya was also noticed. At Val d'en Bas (site 73 in Fig. 1), below a volcanic crust dated at 250 ka ago (Cross et al., 1986), a Pinus forest with Abies and other mesophytes such as Carpinus and Juglans is recorded, linked with the warmest period of an interglacial. In the upper part of this sequence, colder and arid conditions are revealed by the dominance of Pinus. Abies and Pinus are also the main tree taxa of the nearby Plà de les Presses (site 68 in Fig. 1; Pérez-Obiol et al., 1986), at the same time. The base of Plà de l'Estany (site 67 in Fig. 1; Burjachs, 1990, 1994) recorded a later colder phase with steppe expansion (Pinus, Poaceae and Asteraceae), dated by the author as MIS 6, before the last interglacial. Pollen and charcoal studies from the Cuesta de la Bajada palaeontological site, in Teruel (site 58 in Fig. 1; Santonja et al., 2000, Uzquiano unpublished data, respectively) show Juniperus thurifera remains (>80\%) with a slight presence of Pinus sylvestris-type $(7.5 \%)$ at an estimated age of $>300$ ka (>MIS 9: Santonja, pers. comm.), associated to fauna and Mousterian lithic remains. Pollen analyses show that during MIS 6 an open landscape dominated by grasses and scattered Pinus, with some steppe elements (Santonja et al., 2000). 
The Acheulean-Mousterian, Lezetxiki archaeological sequence in Guipúzcoa (site 17 in Fig. 1), northern Spain, attributed to the end of the Middle Pleistocene, shows Pinus forests with Quercus, Castanea, Carpinus and Juglans (Sánchez-Goñi, 1988, Isturitz and Sánchez-Goñi, 1990, Sánchez-Goñi, 1992). Nearby, at the open-air Palaeolithic settlement of Irikaitz (site 10 in Fig. 1; Arrizabalaga et al., 2003, Ruiz-Alonso, 2004) the floristic assemblage is attributed to an interglacial period (Eemian or Holsteinian) or, at least for the lowest levels, to the Cromerian (Arrizabalaga and Iriarte, 2005). Charcoal remains commonly include deciduous Quercus (between 50-70\%), Alnus (6-17\%), Corylus (6-15\%) and Fagus, Salix, Rosaceae, Fraxinus and Acer. Sporadic evidences of Carpinus, Ulmus, Frangula alnus, Populus and Fabaceae are also noticed.

Several Middle Pleistocene palaeontological sites and fluvial terrace deposits have been studied in central Iberia. The longest is from The Galería, in the Atapuerca area, Burgos (site 38 in Fig. 1), which reaches $3 \mathrm{~m}$ depth (García-Antón and Sainz-Ollero, 1991), and is dated to 256 $\mathrm{ka}$ at the bottom and $200 \mathrm{ka}$ at the top of the deposit (Berger et al., 2008). Being the only relatively continuous sequence of the site, it displays hiatuses and sections with poor pollen preservation (García-Antón and Sainz-Ollero, 1991, Cattani et al., 1994, García-Antón, 1995, 1998, Burjachs, 2001). Galería's pollen record from Atapuerca is dominated by deciduous and evergreen Quercus and, occasionally, high frequencies of Pinus and Cupressaceae. Palynological diversity is high and includes Mediterranean (Olea, Pistacia, Phillyrea, Myrtus, Vitis, Celtis and Ceratonia) and temperate woody taxa (Betula, Corylus, Carpinus, Alnus, Fagus, Acer, Juglans, Castanea, Platanus and Salix) (Fig. 5) that fluctuate suggesting shifts in a mosaic landscape through time. The oldest phase is milder, as suggested by Fagus and Ericaceae. Afterwards, Mediterranean landscapes with Olea preceded a parkland steppe with Pinus, Poaceae and Asteraceae. Finally, a temperate Mediterranean forest developed (Fig. 5). 
In the vicinity, the palaeontological sites of Torralba and Ambrona (Soria, sites 36 and 49 in Fig. 1, respectively, and around $150 \mathrm{~m}$ a.s.l. higher than Atapuerca), show open vegetation with Pinus parkland. In the first published study from Torralba (Menéndez-Amor and Florschütz, 1963), a steppe extension of Poaceae, Chenopodiaceae and Pinus was dated as from the Mindel-Riss period using faunal remains. More recent papers for Ambrona (Howell et al. 1995) and for both sites (Ruiz-Zapata et al., 2003b) also show the dominance of Pinus, but in alternation with Juniperus and phases of Poaceae, Artemisia and other composites. Other tree taxa such as Quercus, Castanea, Fagus, Alnus, Betula, Juglans, Salix, Ulmus and Olea are also present (Ruiz-Zapata et al., 2003b). Macro-remains of Pinus sylvestris have been identified in Torralba by Postigo (2003). Both Middle Pleistocene sites are not synchronous. In fact, Ambrona seems to have been occupied prior to Torralba (Pérez-González et al., 1997).

The pollen analyses of hyaena coprolites from Villacastín in Segovia (site 51 in Fig. 1; Carrión et al., 2007), attributed to MIS 6, also show a mosaic of open and wooded habitats with abundant Pinus and Juniperus, steppe-grassland areas and patches of mixed Quercus forest. In the same region, Menéndez-Amor and Florschütz (1963) published the sequence of Villaverde in Madrid (site 52 in Fig. 1) noticing a a similar steppe landscape of Poaceae, Chenopodiaceae and Pinus. The Formación Pinedo on the Tagus terraces (site 41 in Fig. 1; Martín-Arroyo et al., 1995, 1996a, Martín-Arroyo, 1998, Ruiz-Zapata et al., 2004) reveals a shifting mosaic of Pinus and Quercus, with continuous occurrences of Olea, Juniperus, Cistaceae and minor evidences of Betula, Castanea, Ulmus, Juglans, Alnus, Fraxinus and Salix. The authors attribute this alternation to different periods within the Riss glaciation (probably corresponding to MIS 9, 8, 7 and 6).

The peatbog of Padul in Granada (site 93 in Fig. 1) provides the longest pollen sequence from southern Spain. According to Florschütz et al. (1971) (but see controversy in Pons and Reille, 1988), the base of the sequence would include the Mindel-Riss interglacial and the Riss 
period. Pollen records depict an alternation of cold-steppe landscapes of Pinus, Artemisia, Chenopodiaceae and Ephedra with more temperate phases such as: i) the Granada interglacial (Mindel-Riss, Holstein) with significant forest development (arboreal pollen, AP, 60-70\%) of Abies, Tsuga, Fagus, Quercus, llex, Juglans and Vitis; or ii) the Padul interstadial (during the Riss glaciation), where increases of Quercus, Fagus, Ilex and Abies are evident. Finally, the River Aguas sequence in Almería, dated as MIS 6, is characterized by low arboreal pollen percentages (Pinus, evergreen Quercus and Olea) while steppe taxa (Artemisia, Chenopodiaceae, Ephedra, Lygeum and Asteraceae) and shrubs dominate (Thymelaeaceae, Myrtus and Cistaceae) suggesting dry climate conditions (Schulte et al., 2008).

The Homo heidelbergensis-neanderthalensis site of Cueva Negra del Estrecho del Río Quípar in inland Murcia, southeastern Spain (site 82 in Fig. 1), provided palynological results (Carrión et al., 2003) with considerable diversity of trees and shrubs, including mesophytic conifers (Pinus pinaster, Taxus), broad-leaf (Quercus, Corylus, Acer, Arbutus, Ulmus and Salix) and warm-loving taxa (Olea, Pistacia, Phillyrea and Cistus). Based on Walker et al. (1998)'s chronostratigraphical inferences, these spectra were contextualized by Carrión et al. (2003) within the Late Pleistocene. Ulterior dating combined with palaeontological findings suggest an age older than 0.5 Ma (Walker et al., 2006, Scott and Gibert 2009), but the correspondence with the climatostratigraphy of the Middle Pleistocene is still to be elucidated.

Marine pollen sequences embracing the Middle Pleistocene: ODP 976 (site 112 in Fig. 1; Combourieu-Nebout et al., 1999), MD95-2042 (site 109 in Fig. 1; Sánchez-Goñi et al., 1999) (Fig. 6), MD01-2443 (site 105 in Fig. 1; Roucoux et al., 2006) and MD01-2447 (site 106 in Fig. 1; Desprat et al., 2006, 2007), show similar general patterns than continental records. Thus, steppe stages are characterized by Ephedra, Artemisia and Chenopodiaceae, occasionally with Juniperus, while temperate phases are featured by deciduous Quercus, Corylus, Betula, Carpinus, and Mediterranean elements. Olea and evergreen Quercus maxima represent thermic 
stages both in marine (MD01-2443: site 105 in Fig. 1; Roucoux et al., 2006) and inland pollen records (i.e. Atapuerca: site 38 in Fig. 1; García-Antón and Sainz-Ollero, 1991, or Formación Pinedo: site 41 in Fig. 1; Martín-Arroyo et al., 1995). Pinus pollen, generally over-represented in marine sediments, is difficult to interpret in terms of woodland cover. In any case, continental records with high values for Pinus pollen during the Middle Pleistocene correlate with marine records, thus indicating that pinewoods were widespread.

Finally, the Middle Pleistocene history of vegetation traces a modern flora with the relictual presence of Keteeleria, Platanus, Carya, Ostrya, and Cedrus, among others. Juglans and Castanea, formerly considered as reintroduced, never became extinct during this period (Sánchez-Goñi, 1988, García-Antón et al., 1990, Carrión and Sánchez-Gómez, 1992, Postigo et al., 2007, 2009).

\section{3.- The Late Pleistocene $(125-11.5 \mathrm{ka})$}

More data with a generally better chronological control are available for Late Pleistocene Iberian sites, but too many geographical and temporal discontinuities persist (Table 1, Fig. 7). The scarcity of Eemian records and of long sequences is noteworthy. Thereafter, we provide a regional description of palynological and macrobotanical records.

\subsection{1.- North / Northwestern Iberia}

Most of the available information is from 80 ka BP onwards (Table 1, Fig. 7), with the exception of Area Longa's pollen record (site 2 in Fig. 1), which spans from MIS $5 c$ to MIS 3 (Gómez-Orellana et al., 2007). The base of Area Longa (MIS 5c) is dominated by deciduous woodland (Alnus, Quercus robur type, Corylus, Betula and Carpinus) with relatively high contributions of Fagus. During the Lower Pleniglacial (MIS 4), high percentages of Erica, Calluna and Poaceae indicate heath and temperate grassland as predominant vegetation types with low 
prevalence of conifers and persistence of broad-leaf trees such as Quercus robur type, Corylus, Fagus, Carpinus, Ulmus and Ilex (Fig. 8). The possibility of long-distance pollen transport and sedimentary reworking has been shown to be negligible (Gómez-Orellana et al., 2007). In two Cantabrian caves (Covalejos and El Castillo, sites 4 and 6 in Fig. 1, respectively), charcoal remains assigned to the MIS 4 (Uzquiano, 1992b, 2007, in press) testify the presence of Pinus sylvestris-type and Betula. At El Castillo cave, above the Level 22, dated at $<89$ ka BP (U-Th date), an alternation of these taxa and the occurrence of Fagus, are noticed (Uzquiano, 1992a, 2007).

During the MIS 3, three phases of deciduous woodland expansion are observed in Area Longa (site 2 in Fig. 1): i) before $42{ }^{14} \mathrm{C}$ uncal. ka BP with dominance of deciduous Quercus; ii) a Betula phase between 42-35 uncal. ka BP and iii) a new predominance of deciduous Quercus around 33 uncal. ka BP (Gómez-Orellana et al., 2007). These cycles, along with smaller-scale fluctuations, correlate well with the ice-core record, including a vegetation response to Heinrich events and Dansgaard-Oeschger cycles. In addition, intermittent pollen occurrences of mesothermophytes suggest nearby refugial areas. The oscillations observed in Area Longa during MIS 3 parallel those at Oia and Moucide (sites 20 and 19 in Fig. 1, respectively; Gómez-Orellana, 2002, Gomez-Orellana et al., 2007), Lagoa de Lucenza (site 14 in Fig. 1; Muñoz-Sobrino et al., 2001), Laguna Sanguijuela (site 32 in Fig. 1; Muñoz-Sobrino et al., 2004), Lleguna (site 34 in Fig. 1; Muñoz-Sobrino et al., 2004), and Lagoa de Marinho (site 31 in Fig. 1; Ramil-Rego et al., 1993a) pollen records.

Anthracological work in Asturian and Cantabrian caves confirms this mosaic of vegetation (Uzquiano, 2008) (Fig. 9). At El Esquilleu cave (site 8 in Fig. 1), the charcoal flora from the upper levels (39-36.5 uncal. ka BP) is diverse. Pinus sylvestris-type decrease (from $60 \%$ to $<10 \%$ ) in favour of a varied group of taxa such as Betula, Juniperus, Corylus, Fraxinus, Salix, Sorbus aria, Prunus avium, Laurus nobilis, Rhamnus alaternus, Arbutus unedo, Fabaceae, and Ericaceae, 
amongst others (Uzquiano 2008). At El Castillo and Covalejos caves (sites 6 and 4 in Fig. 1, respectively), Betula is also dominant during the interval 42-37 uncal. ka BP with an outstanding presence of Sorbus, and small amounts of Pinus sylvestris-type, Corylus avellana, Hippophae rhamnoides, Laurus nobilis, Rhamnus alaternus, Ericaceae and Fabaceae (Uzquiano, 2008). E Conde cave (site 7 in Fig. 1) reveals Pinus sylvestris-type dominance in association with Betula, Sorbus and the presence of deciduous Quercus. In addition, the earliest evidence of Quercus ilex charcoal in the Cantabrian region is recorded (>38 and around 31-29 uncal. ka BP) (Uzquiano et al., 2008), in correspondence with the last phase of the Area Longa MIS 3 sequence (site 2 in Fig. 1). In Cobrante cave (site 3 in Fig. 1), Betula is dominant (>90\%) around 30 uncal. ka BP and, in Sopeña rockshelter (site 22 in Fig. 1), Juniperus is the main taxon (53\%) alternating with heathland shrubs (26\%), some Pinus sylvestris-type evidences and Betula, Salix and Fabaceae (Uzquiano, unpublished data) showing the climatic deterioration prior to MIS 2.

Pollen spectra and charcoal remains assigned to MIS 2 reveal open landscapes from 21,000 to 17 cal. ka BP (Lago de Ajo site 12 in Fig. 1; Lagoa de Lucenza, site 14 in Fig. 1; Laguna Sanguijuela, site 32 in Fig. 1; La Roya, site 29 in Fig. 1; Altamira cave, site1 in Fig. 1; Cobrante cave, site 3 in Fig. 1), indicating cold and dry conditions with Artemisia and PinusJuniperus woods as dominant at a regional scale, but with deciduous trees in all localities (McKeever, 1984, Uzquiano, 1992a, Allen et al., 1996, Muñoz-Sobrino et al., 2004, 2007). Salix and Juniperus were the main taxa exploited by Cantabrian prehistoric humans in those times (Uzquiano, 1992a, 1992b, in press). During the Lateglacial, pollen sequences show the expansion of Pinus and Juniperus, as well as increasing frequencies of deciduous taxa, mainly Betula and Quercus were obtained (Lago de Ajo, site 12 in Fig. 1: Mckeever, 1984, Allen et al., 1996; Lagoa de As Lamas, site 30 in Fig. 1: Maldonado, 1994; La Roya, site 29 in Fig. 1: Allen et al., 1996; Pozo de Carballal, site 21 in Fig. 1: Muñoz-Sobrino et al., 1997; Lagoa de Marinho, site 31 in Fig. 1: Ramil-Rego et al., 1993a, Muñoz-Sobrino et al., 2007). Similar results are shown by 
charcoal analyses from cave sites, with deciduous and evergreen Quercus, Corylus, Castanea, Fagus, Acer and Betula (Uzquiano 1992a, 1998), associated with the dominant taxa Juniperus, Salix, Fabaceae and Pinus (i.e. Los Azules and Las Caldas in Asturias, sites 18 and 16 in Fig. 1, and Altamira, Cobrante, El Linar, Cualventi, La Pila and Las Aguas in Cantabria, sites 1, 3, 9, 5, 11 and 15 in Fig. 1, respectively) (Uzquiano, 1992a, in press). Both pollen and charcoal depict steppe expansions as particularly significant from 12,600 to 11,700 cal. yr BP (Uzquiano, 1998, Muñoz-Sobrino et al., 2007).

In Charca da Candiera (site 26 in Fig. 1), at the Serra da Estrela (Portugal), Quercus forest developed early between 14,060-12,850 cal. yr BP, followed by a rapid contraction and a new steppe development (van der Knaap and van Leeuwen, 1997). At the Guadiana estuary (site 28 in Fig. 1), the core CM5 (Beliche, Portugal) also recorded an evergreen and semi-deciduous Quercus forest without the sclerophyllous taxa that define the Holocene in the area (Olea, Phillyrea and Pistacia) at 13,000-12,840 cal. yr BP (Fletcher et al., 2007). The arrival of the Younger Dryas is characterized by the increase of Pinus, low Quercus percentages and the expansion of Juniperus, Ephedra distachya type, Artemisia and Centaurea (Fletcher et al., 2007).

In the Portuguese Estremadura, most information has been obtained from the study of archaeological charcoal (Aubry et al., 2001, Figueiral, 1993, 1995, Figueiral and Terral, 2002, Zilhão et al., 1995) recovered from one open-air site (Cabeço de Porto Marinho, site 25 in Fig. 1), and four caves (Lapa do Anecrial, Buraca Escura, Buraca Grande and Gruta do Caldeirão, sites 33, 23, 24 and 27 in Fig. 1). In the lowlands, the earliest data assigned to the MIS 3 were obtained in the Aurignacian (33,000 uncal. yr BP) and Gravettian (23,500 uncal. yr BP) levels from Cabeço de Porto Marinho (site 25 in Fig. 1). In this site, the assemblage (Pinus sylvestristype, Pinus pinaster-pinea, Fabaceae and Erica) seems to show open steppe-like communities, although evergreen Quercus are also present. During the MIS 2, plant species usually associated with open mountain-type habitats, are identified by charcoal at Lapa do Anecrial (site 33 in Fig. 
1), Buraca Escura $(21,820 \pm 200$ uncal. yr BP; site 23 in Fig. 1), Buraca Grande $(23,920 \pm 300$ and $17,850 \pm 200$ uncal. yr BP; site 24 in Fig. 1) and Gruta do Caldeirão (Solutrean levels; site 27 in Fig. 1). The plant assemblage identified includes Pinus sylvestris-type, Fabaceae (in all sites), Erica (Lapa do Anecrial) and Buxus sempervirens (Buraca Escura, Buraca Grande, Gruta do Caldeirão). However, at Buraca Grande (site 24 in Fig. 1) and Gruta do Caldeirão (site 27 in Fig. 1), more thermophilous elements such as Olea, evergreen Quercus, Rhamnus and Phillyrea were identified, indicating that these plants could have survived in sunlit slopes of protected areas. Western Iberia could thus be also considered as a refuge area for thermophilous taxa during the colder periods of the Pleistocene. This would explain the early Holocene development of species such as Olea (Figueiral, 1998). Additional charcoal data for the late MIS 2 are available from Cabeço de Porto Marinho (site 25 in Fig. 1), where Magdalenian levels testify the remarkable spread of Mediterranean Pinus (pinaster - pinea) and the gradual disappearance of Pinus sylvestris-type. The charcoal assemblages are here dominated by evergreen species and only two deciduous elements are recorded (Quercus and Fraxinus) (Figueiral, 1993, Zilhao et al., 1995). At that time, Pinus woodland appeared to replace more open plant communities in western Iberia.

\subsection{2.- Central Iberia}

In Central Iberia, no long palaeobotanical sequences are available for the Late Pleistocene. The oldest data from MIS 5 (110-80 ka BP) have no temporal continuity due to the existence of hiatuses and/or the short timespan recorded (Formación Pinedo, in Toledo, site 41 in Fig. 1: Martín-Arroyo et al., 1999). Pollen data from Formación Pinedo resemble those obtained for the rest of the Iberian Peninsula. Pinus is accompanied by relatively dense Mediterranean scrub with Olea, Juniperus and evergreen Quercus, along with some riparian elements such as Salix. The development of the Mediterranean vegetation is in agreement with the current 
bioclimatic characteristics of these areas of Central Spain (Blanco-Castro et al., 1997) and the typical Eemian vegetation formations from Mediterranean areas, where Olea dominates (Tzedakis, 1994, Carrión et al., 1998, Sánchez-Goñi et al., 1999, Klotz et al., 2003). The study of Carrión et al. (2007) at Villacastín in Segovia, and Torrejones in Guadalajara (sites 51 and 50 in Fig. 1, respectively), explored vegetation change during the period $80,000-60,000$ years ago (MIS 4). The pollen assemblages indicate the existence of woody taxa (Quercus, Taxus, Betula, Castanea, Prunus, Ericaceae and Juniperus) in a steppe landscape dominated by grasses, with abundant Artemisia and other composites, and the occasional presence of Ephedra nebrodensis and Caryophyllaceae. Unpublished data from anthracological analysis in Camino rockshelter (site 40 in Fig. 1) and Buena Pinta cave (site 39 in Fig. 1), both in Madrid, reveal poor charcoal remains preservation, Pinus sylvestris-type being the most relevant taxon while Quercus, Fraxinus, Sorbus/Crataegus, Pomoideae, Salix and Populus are also present (Uzquiano, pers. comm.).

The palaeoenvironmental reconstruction available for MIS 3 and 2 is only based on three sequences from Ciudad Real: Tablas de Daimiel-TD (site 48 in Fig. 1), in the National Park of Tablas de Daimiel (Valdeolmillos, 2005, Valdeolmillos et al., 2003), Fuentillejo maar lake (site 42 in Fig. 1; Vegas et al., 2008), in the central Spanish volcanic Field of Calatrava, and Arenales de San Gregorio-TASG-1 (site 37 in Fig. 1; Ruiz-Zapata et al., 2000) in the NW of Ciudad Real. The sequence TD (site 48 in Fig. 1) presents frequent sterile levels but some inferences can be made (Valdeolmillos et al., 2003). Betula formations are firstly replaced by Pinus and Juniperus later, culminating with the development of an open landscape where Poaceae and Chenopodiaceae dominate. These spectra reflect cold and arid conditions and they are associated to Heinrich events: $\mathrm{H} 4$ at about 36,000 uncal. ${ }^{14} \mathrm{C}$ years (between 11.2 and $10.8 \mathrm{~m}$ depth of the TD sequence) and $\mathrm{H} 3$ at about 28,000 uncal. ${ }^{14} \mathrm{C}$ years and located between 7.8 and $7.4 \mathrm{~m}$ depth (Valdeolmillos et al., 2003). Similar conditions are detected in the Fuentillejo sequence (FUENT- 
1, site 42 in Fig. 1) by Vegas et al. (2008) during the MIS 2, with possible temperature fluctuations during arid phases. The sequence Arenales de San Gregorio (site 37 in Fig. 1) corresponds to a clay dune dated by OSL/TL to the Last Glacial Maximum (LGM): 23-22 ka (Ruiz-Zapata et al., 2000). At that time, the strong seasonal variation and the scarcity of woody vegetation would facilitate the existence of aeolian processes and dune formations as Arenales de San GregorioTASG-1. Pollen analysis reveals the existence of steppe vegetation adding to low occurrences of Pinus, Juniperus, Quercus, Betula, Corylus and Castanea. Finally, a short pollen record was carried out at Mesa de Ocaña-MO in Toledo (site 46 in Fig. 1), by Ruiz-Zapata et al. (2000). This study was done on a sandy loess formation, dated as Younger Dryas (11 ka BP) using IRSL. Along $2.70 \mathrm{~m}$ depth, a progressive loss of the arboreal vegetation, mainly constituted by Pinus, takes place. Then, Pinus is replaced by Juniperus and finally, by steppe formations. Scattered occurrences of Quercus, Betula, Corylus and Alnus are also recorded.

Ruiz-Zapata et al. (2003a) studied a pollen core from Laguna Grande (site 45 in Fig. 1), at Sierra de Neila in the Iberian System, which covers the cold events H2 (c. 21 cal. ${ }^{14} \mathrm{C}$ ka BP) and $\mathrm{H} 1$ (c. 14 cal. ka ${ }^{14} \mathrm{C} \mathrm{BP}$ ). The pollen assemblages are typical of cold and arid conditions (Artemisia and Chenopodiaceae dominance), but Betula, Fagus, Corylus, Ilex and evergreen and deciduous Quercus developed after both Heinrich events indicating the abrupt climatic oscillations that characterized the Lateglacial period. More data from this period are shown in Hoyos de Iregua (site 43 in Fig. 1; Gil-García et al., 2002), Laguna del Hornillo (site 44 in Fig. 1; Gómez-Lobo, 1993) and Quintanar de la Sierra sequence (site 47 in Fig. 1; Peñalba et al., 1997). All these sites reveal an herbaceous vegetation with isolated Pinus and Betula, shaping a savannah-like landscape. The presence of meso-thermophilous taxa such as deciduous Quercus, Corylus and evergreen Quercus is not negligible. During the Younger Dryas event, an important tree reduction is observed. 


\subsection{3.- Northeastern Iberia}

The overall picture is not different from the former, and includes Pinus forests with or without Juniperus, Juniperus-dominated formations, mixed Pinus-Quercus forests, patches of mesophilous trees, savannah-like vegetation, grasslands and steppes, which fluctuate in response to stadial/interstadial shifts. Pollen data concerning MIS 5 lack chronological control, although the study of a new long pollen sequence covering all the Late Pleistocene and Holocene is currently in progress (El Cañizar de Villarquemado, in Teruel, site 59 in Fig. 1: GonzálezSampériz, in preparation).

The Pla de l'Estany pollen record (site 67 in Fig. 1; Burjachs, 1990) shows in its zone B an important tree component dominated by Abies, Fagus, deciduous Quercus, Carpinus and other mesophytes, pointing to the Eemian s.s. (5e) during MIS 5. Concerning MIS 4, only Abric Romaní (Fig. 7 and Fig. 10), near Barcelona (site 53 in Fig. 1), shows a well-dated palaeobotanical information during $70-40 \mathrm{ka} \mathrm{BP}$, with tree pollen percentages of $40-60 \%$, dominated by Pinus but with continuous presence of Juniperus, Rhamnus, Quercus, OleaPhillyrea, Betula, Fagus, Pistacia and other woody taxa (Burjachs and Julià, 1994). Similar data are provided at Pla de l'Estany (site 67 in Fig. 1; Burjachs, 1990) and, during the MIS 3, at l'Arbreda cave (site 63 in Fig. 1; Ros Mora, 1987, Burjachs, 1993) and Banyoles (site 54 in Fig. 1; Pérez-Obiol and Julià, 1994); the hyena coprolites from Gabasa cave (site 61 in Fig. 1; GonzálezSampériz et al., 2003) and El Portalet (site 60 in Fig. 1; González-Sampériz et al., 2006) in Huesca; and San Juan de Mozarrifar in Zaragoza (site 70 in Fig. 1; González-Sampériz et al., 2005), show a tree component dominated by Pinus and Juniperus with the presence of evergreen and deciduous Quercus and other woods such as Betula, Corylus, Alnus, Tilia, Buxus and even Olea-Phillyrea. The xerophytic component is composed of Poaceae, Asteraceae, Chenopodiaceae, Ephedra fragilis and distachya types and/or Artemisia in the whole sequences. Both pollen and charcoal reveal a mosaic-like landscape dominated by conifers (Pinus sylvestris- 
type followed by Juniperus), associated with evergreen and deciduous Quercus, Corylus, Buxus sempervirens, Acer opalus and A. monspessulanum, Sorbus domestica, Rhamnus cathartica, $R$. alaternus, Prunus amygdalus, and even Fagus sylvatica, as shown at Cova 120 (site 57 in Fig. 1) and l'Arbreda cave (site 63 in Fig. 1) by anthracological analyses (Agustí et al., 1987, Ros Mora, 1987, Burjachs and Allué, 2003).

The MIS 2 in north-eastern Spain is served by more substantial information. Both Banyoles (site 54 in Fig. 1) and l'Arbreda cave (site 63 in Fig. 1) show savannahs of Pinus with Juniperus, along with the presence of Betula, Acer, Corylus, deciduous and evergreen Quercus, Tilia, Alnus, Ulmus, Salix and Olea among others, indicating the location of regional refugial areas in a patched landscape still dominated by steppes of Poaceae and Artemisia (Pérez-Obiol and Julià, 1994). In the Central Pyrenees a relative abundance of palynological data occurs in the Gállego valley, with Tramacastilla (site 71 in Fig. 1; Montserrat, 1992) and El Portalet sequences (González-Sampériz et al., 2006), amongst others (González-Sampériz et al., 2005). At El Portalet peat bog (site 60 in Fig. 1), a sedimentary hiatus coeval to the LGM and associated to a glacier readvance, is observed between 22-18 cal. ka BP. After that, with the beginning of the Lateglacial period, some mesophytes (mainly Betula) as well as Pinus and Juniperus develop, behaving like pioneer trees during the Bølling and Allerød warm phases. Lowland records of this area, as Salada de Mediana (site 69 in Fig. 1; Valero-Garcés et al., 2000a, 2000b, GonzálezSampériz et al., 2003) provide further, circumstantial evidence for the existence of regional and/or local populations of Juniperus, evergreen and deciduous Quercus, Corylus, Betula, Salix, Alnus, Juglans, Pistacia, Myrtus, Rhamnus, and Olea. The high frequencies of Corylus pollen at this sequence can be interpreted as the local existence of a refugial area under a regionally savannah-steppe dominance. Another striking feature of the Salada de Mediana pollen diagram is its relatively high AP values by comparison with present-day xeromorphic vegetation (evergreen Quercus: 10-20\%, Corylus: 10-40\%, Pinus: 30-60\% and Juniperus: 10-25\%). 


\subsection{4.- South-Southeastern Iberia}

The Levant and south-southeastern areas show a particularly high diversity of landscapes during the Late Pleistocene, including mountain grasslands and lowland steppes, coniferous savannahs and forests in mid-altitudes, and refugial populations of trees and shrubs in coastal shelves and intramontane valleys during the coldest stages (Carrión et al., 2008). The most frequent tree genera included Pinus, Quercus, Juniperus, Abies, Corylus, Betula, Alnus, Ulmus, Salix, Castanea, Fraxinus, Juglans, Acer, Sorbus, Taxus, Olea, Pistacia, Phillyrea, Arbutus and Myrtus.

The most significant palaeobotanical records are the nearby Padul and Carihuela sequences (sites 93 and 78 in Fig. 1, respectively), in Granada (Florschütz et al., 1971, Pons and Reille, 1988, Carrión, 1992a, Carrión et al., 1998, 1999, Fernández et al., 2007), covering the majority of the Late Pleistocene (MIS 5, 4, 3 and 2) (Fig. 7). No other data are referenced in the Levant in respect to MIS 5 and 4, except an assignment of "pollen zone A" from Laguna de Villena (site 87 in Fig. 1), in Alicante (Yll et al., 2003), dated as older than 47,450 uncal. ${ }^{14} \mathrm{C} \mathrm{BP}$ and attributed by the authors to the Early Würmian Pleniglacial (around MIS 4) based on the high percentages of steppe taxa ( $40 \%$ of Artemisia and abundance of Ephedra). It is noticeable that at the same level of Laguna de Villena, AP also reaches high values and it is composed mainly by Pinus followed by Juniperus, evergreen Quercus and the presence of deciduous Quercus, Corylus, Betula, Alnus, Ulmus, Tilia and Olea. These spectra are especially relevant to demonstrate the continuous presence of arboreal populations in the region, as well as during the MIS 3 in Navarrés (site 91 in Fig. 1; Carrión and van Geel, 1999), Laguna de San Benito (site 86 in Fig. 1; Dupré et al., 1996) and Malladetes cave (site 90 in Fig. 1; Dupré, 1988) in Valencia, Cova Beneito in Alicante (site 79 in Fig. 1; Carrión and Munuera, 1997) and Perneras cave in Murcia (site 94 in Fig. 1; Carrión et al., 1995). All these sequences show an important Mediterranean component with evergreen Quercus, Olea, Pistacia and Myrtus, despite the 
existence of steppe formations, and next to coniferous woodlands with mesophytes. In addition, a significant presence of hyper-thermophilous scrub can be observed in the Mousterian sites of Perneras cave (site 94 in Fig. 1) and Sima de las Palomas (site 99 in Fig. 1) in the Murcian coast (i.e., Periploca, Osyris, Withania, Maytenus, and Myrtus) (Carrión et al., 1995, 2003).

The Lateglacial period is also characterized in this area by a great biodiversity of vegetation landscapes, which include Pinus forests with or without Juniperus, Mediterranean formations with thermophytes, deciduous trees, grasslands and steppes (see the pollen diagrams of Túnel dels Sumidors in Valencia (site 101 in Fig. 1; Dupré, 1988), Salines in Alicante (site 95 in Fig. 1; Giralt et al., 1999) or Algarrobo cave (site 74 in Fig. 1; Munuera and Carrión, 1991, Carrión et al., 2003), besides the previously mentioned sites for MIS 3.

In respect to charcoal remains (Fig. 9), only six archaeological sites (caves and rockshelters) with anthracological analyses are available from southeastern Iberia: Cova Beneito, Tossal de la Roca, Cova de Les Cendres, La Ratlla del Bubo, Cova Bolumini and Santa Maira (sites 79, 100, 81, 85, 80 and 97 in Fig. 1 and Table 1, respectively). MIS 3 conditions are shown by data from Cova Beneito (site 79 in Fig. 1), with mainly Pinus sylvestris-type and scant Juniperus phoenicea (Uzquiano unpublished data). During the Lateglacial, Pinus nigra dominated an assemblage also formed by Juniperus, Fabaceae, Buxus sempervirens, Pistacia terebinthus and P. lentiscus, Olea europaea var. sylvestris, Ephedra, Rhamnus, Crataegus, Fraxinus oxyphylla, Ficus and Cistus. Quercus faginea and Q. ilex-coccifera increased when the Holocene approaches (Badal, 1991). At Tossal de la Roca (site 100 in Fig. 1), for example, Quercus faginea type had its first appearance around 15 uncal. ${ }^{14} \mathrm{C}$ ka BP, developing a continuous presence from 12.4 uncal. ${ }^{14} \mathrm{C}$ ka BP on, and became dominant in the Early Holocene (Uzquiano, 1988, Cacho et al., 1995) while in Santa Maira (site 97 in Fig. 1), both in Alicante, Pinus halepensis, P. pinea-pinaster, Rosmarinus and Hedera were present along with evergreen Quercus (increasing frequencies) and deciduous Quercus (which decreased in the upper part of 
the Lateglacial, Magdalenian occupations), marking the transition to the Holocene (Aura et al., 2005).

As mentioned earlier, the Late Pleistocene floras of southern Iberia are mainly known due to two long records (Fig. 11): Padul peat bog (site 93 in Fig. 1; Florschütz et al., 1971, Pons and Reille, 1988) and Carihuela cave (site 78 in Fig. 1; Carrión et al., 1998, 1999, Fernández et al., 2007), which add to some short pollen sequences (see Table 1) and the hyena coprolites pollen records from Las Ventanas and Gorham's caves (sites 88 and 83 in Fig. 1; Carrión et al., 2001 and 2008, respectively). The main features of this period are:

- a MIS 5 (Eemian period, last Interglacial) dominated by Olea and Quercus formations with a great diversity of conifers, deciduous and evergreen, mesothermophilous woods: Pinus, Abies, Cedrus, Taxus, Juniperus, Alnus, Betula, Acer, Corylus, Ulmus, Fraxinus, Buxus and Vitis in Padul (site 93 in Fig. 1; Pons and Reille, 1988) and Pinus, Juniperus, Alnus, Betula, Corylus, Ulmus, Fraxinus, Juglans, Salix, Castanea, Pistacia, Myrtus, Buxus, Ericaceae and Phillyrea in Carihuela (site 78 in Fig. 1; Carrión et al., 1998);

- During the MIS 4- MIS 3 an alternation of i) Artemisia, Poaceae, Asteraceae, Chenopodiaceae and Ephedra distachya steppes and, ii) forest taxa development that includes mainly Pinus and some Quercus, Oleaceae and other trees. Apart from Padul and Carihuela, this pattern is seen at Boquete de Zafarraya and Bajondillo caves in Málaga (sites 77 and 76 in Fig. 1; Lebreton et al., 2006 and López-Sáez et al., 2007, respectively); and Gorham's cave in Gibraltar (site 83 in Fig. 1; Carrión et al., 2008). Charcoal remains indicate Pinus as dominant taxum with Pinus nigra (Nerja cave in Málaga, site 92 in Fig. 1: Badal, 1991; Aura et al., 2002) and Pinus pinea-pinaster (Gorham's cave in Gibraltar, site 83 in Fig. 1: Carrión et al., 2008), followed by Fabaceae, Juniperus, Cistus, Rhamnus-Phillyrea, Olea, Prunus, Sorbus-Crataegus, Erica and Quercus sp. 
- a Lateglacial Quercus colonisation suggesting the proximity of glacial refugia for woody taxa. The mid-elevation Siles lake record in Jaén (site 98 in Fig. 1) is especially relevant here, because its pollen diagram shows a continuous presence of arboreal populations, a "tree reservoir", in the Andalusian mountain ranges at middle altitudes (Carrión, 2002a). A littoral pollen sequence from San Rafael, Almería (site 96 in Fig. 1; Pantaleón-Cano et al., 2003) also shows continuous curves for evergreen and deciduous Quercus, as well as for Olea, during the LGM and the Lateglacial. Charcoal data from Hoyo de la Mina in Málaga (site 84 in Fig. 1; Uzquiano, unpublished data) and Gorham's cave (site 83 in Fig. 1; Carrión et al., 2008) reflect, at 18 cal. ${ }^{14} \mathrm{C}$ ka BP, a dominant Quercus ilex - Olea - Pinus pinaster-pinea complex followed by Fabaceae, deciduous Quercus, Pistacia lentiscus, Phillyrea, Juniperus, Fraxinus, Salix-Populus, Quercus suber type, Crataegus, Sambucus, Arbutus, Rhamnus alaternus and lycioides, Prunus sp., Cistus sp., Rosmarinus, Lonicera, Smilax or Viscum, while Ambrosio cave, in Almería (site 75 in Fig. 1), shows at around 16.5 cal. ${ }^{14} \mathrm{C}$ ka BP (Rodríguez-Ariza, 2005), a charcoal content dominated by Juniperus sp., followed by Pinus sylvestris-type, Prunus and the presence of Quercus faginea, Quercus ilex-coccifera, Cistus, Rosmarinus and Fabaceae. Similar data were obtained at Nerja cave (site 92 in Fig. 1) and La Ratlla del Bubo rockshelter (site 85 in Fig. 1; Badal, 1991).

\subsection{5.- Marine records}

Nine Iberian margin marine sequences have yielded pollen analyses for the Late Pleistocene period (timespan and coordinates are included in Table 1). They are, from N-NW to SW-S-SE: MD03-2697 (site 107 in Fig. 1; Naughton et al., 2007, Sánchez-Goñi et al., 2008), MD99-2331 (site 111 in Fig. 1; Sánchez-Goñi et al., 2005, Naughton et al., 2007), MD95-2039 (site 108 in Fig. 1; Roucoux et al., 2001, 2005), S075-6KL (site 113 in Fig. 1; Boessenkool et al., 2001), MD95-2042 (site 109 in Fig. 1; Sánchez-Goñi et al., 1999, 2008), SU 8113 (site 114 in Fig. 1; Parra, 1994, Carrión et al., 2000, Magri and Parra, 2002), $8057 \mathrm{~B}$ (site 102 in Fig. 1; 
Hooghiemstra et al., 1992), ODP 976 (site 112 in Fig. 1; Combourieu-Nebout et al., 1999, 2002, 2009) and MD95-2043 (site 110 in Fig. 1; Sánchez-Goñi et al., 2002, Fletcher and Sánchez-Goñi, 2008). Overall, the same vegetation trends and main dominant taxa (excepting Pinus and, evidently, Cedrus inputs from northern Africa) are shown in respect to continental records. Fletcher and Sánchez-Goñi (2008) suggest a strong similarity between the MD95-2043 Alborán record (site 110 in Fig. 1) and the Padul sequence (site 93 in Fig. 1; Pons and Reille, 1988), at a regional point of view. In both records, Quercus ilex, Q. suber and deciduous Quercus type's have a continuous presence and develop during interstadials, in opposition to steppe taxa fluctuations. In addition, Sánchez-Goñi et al. $(1999,2008)$ record in the Portuguese margin (site 109 in Fig. 1), at the MD95-2042 (Fig. 12), a Quercus forest development associated to the last interglacial, with the typical presence of Carpinus and Olea (with low values) that characterize the Eemian Mediterranean period in continental sequences (Tzedakis, 1994, Carrión et al., 1998, Klotz et al., 2003).

\section{4.- Summary remarks}

Vegetation changes recorded in Iberia during the Pleistocene match regional and global climatic changes, in spite of local particularities observed in continental records that respond to the varied mosaic and patched vegetation landscape formed by coeval steppes, savannahs and forests. Regional characteristics emerged as soon as for the Middle Pleistocene, if not earlier: Ericaceae in the Atlantic coast, thermo-mediterranean elements in the south, and broad-leaf trees in the northeastern. Unfortunately, no data are available from each region. The Early Pleistocene already shows glacial periods with very open vegetation, often characterised by a steppe with abundant Asteraceae liguliflorae. Few Middle Pleistocene records exist so far; they show that there are still some plant extinctions (Arctotertiary woody taxa) but their precise timing is still

unknown. Glacial steppes seems to be still dominated by Asteraceae other than Artemisia in the 
$\mathrm{N}-\mathrm{E}$, while Artemisia spread in the inland and the southeast sequences, showing possible moisture differences across the Iberian Peninsula. The Late Pleistocene record is rather well covered, but the Eemian (MIS 5e) still remains very poorly documented. For glacial steppes, both herbaceous assemblages were recorded but Artemisia dominates, excepting in the Cantabrian region. Again, more data are necessary to take into account the dominance of Artemisia in glacial steppes across Iberia as a response to increasing xericity.

The climatic influences are obvious since both pollen and charcoal data allow us to mark a thermic and moisture availability gradient, as in present times, between N-NW regions (with more cool-cold steppes and higher moisture conditions translated to mesophytes expansion during improved climatic conditions) and Mediterranean areas of Iberia (where thermophytes survived during glacial times, and the steppe components imply very dry conditions). Nevertheless, the most significant and common nexus amongst all the lberian territory during the Pleistocene (particularly during the Late Pleistocene) was the set of evidences recorded in terms of refugial areas for mesothermophilous taxa, as we shall discuss later.

\section{5.- Discussion}

5.1.- Controls of vegetation changes during the Pleistocene: Milankovitch cyclicity, suborbital forcing and amplitude of changes

Pleistocene floras of Iberia are strongly dependent on their geographical location and on contrasting topography. Climate forcing on vegetation change has been of crucial importance as well (Tzedakis et al., 2003, Tzedakis, 2007, Claussen, 2008, Claussen et al., 2008, Berger et al., 2008, Fletcher and Sánchez-Goñi, 2008). The most significant changes appear to have occurred in pace with orbital forcing, especially with the replacement of $41 \mathrm{ka}$ obliquity climate cycles by 100 ka rhythm of eccentricity dominated cycles (Raymo et al., 2004, Clark et al., 2006, Lisiecki and Raymo, 2007). These climate changes imply increases of severity and duration of cold 
stages, and have had a strong effect in physical landscape (Head and Gibbard, 2005), including vegetation. Not in vain, they may have been a "coup de grâce" to the disappearance of tree genera like Aesculus, Parrotia and Zelkova (Postigo et al., 2007, 2009).

It is well known that, in orbital frequencies, there is a general correspondence between tree population size and composition, and ice volume extension, marking strong variations between glacial and interglacial periods (Tzedakis et al., 2003). In the Early and Middle Pleistocene successions, Milankovitch cycles have been so far observed in only a few sequences because few go beyond one climatic cycle (i.e. Bòbila Ordis, Atapuerca, Padul and ODP 976). In Bòbila Ordis, glacials and interglacials have been correlated to MIS 36-33 owing to the presence of the Cobb Mountain subchron. Rapid and frequent changes in vegetation are linked to obliquity forcing, but the glacial minima and the interglacial maxima are less extreme than after the end of the Early Pleistocene (Leroy, 2007). The diagrams of Bòbila Ordis, Tres Pins, Padul, Val d'en Bas, Pla de l'Estany, Atapuerca and ODP 976 (see Table 1 for references) show periods of drastic deforestation with $<20 \%$ of mesic pollen component in glacial phase. Some fairly large fluctuations between levels can be also observed in Early-Middle Pleistocene records (Andrade, 1944, Teixeira, 1943, Zbyzewsky, 1958, Suc and Cravatte, 1982, Suc and Popescu, 2005), although each glacial-interglacial cycle of shorter sequences is probably represented only by 1 or 2 samples.

Even though the lengths of pre- and post-temperate phases of the different interglacial floristic compositions have varied through time, the duration of these temperate parts has remained relatively constant (first two thirds of an obliquity cycle and after $1 \mathrm{Ma}$ ago half a precession cycle) throughout at least the last 5 Ma (Leroy and Seret, 1992, Leroy, 2007, Tzedakis, 2007). So, Mediterranean forest expansion during interglacial successions reflect, at the same time, the influence of precessional changes and maximum summer radiation (Tzedakis, 2007). In the ODP 976 core (Combourieu-Nebout et al., 1999, 2009) the obliquity influence is 
superimposed by precession cycles of $21 \mathrm{ka}$ : the usual dynamic is seen as mesothermics replaced by altitude elements and ended with halo-xerophytes. Fletcher and Sánchez-Goñi (2008) remarked on the influence of precession on the amplitude and composition of forest development in MD95-2043.

Suborbital frequencies have been a pervasive feature since, at least, the last $500 \mathrm{ka}$ (Tzedakis et al., 2003). In this sense, peaks of steppe vegetation have been related to North Atlantic influences (mainly Heinrich and Dansgaard-Oeschger events) in pollen diagrams from Iberian marine records (i.e. Roucoux et al., 2001, 2005, Sánchez-Goñi et al., 2005, 2008), but it is not easy to observe the same correlation in the continental domain. Only a few sites such as El Portalet in the Pyrenees (González-Sampériz et al., 2006) show a clear-cut response to abrupt cold events ever since 33 cal. ka BP, including Heinrich event 3 (HE 3), HE 2, Late Glacial Maximum (LGM), HE 1, Oldest Dryas, Older Dryas, Intra Allerød Cold Period (IACP), Younger Dryas and 8.2 ka event. The chronological framework and resolution analyses could be the cause for these marine-continental data differences because suborbital forcings imply abrupt changes that require very high-resolution data while orbital influences are more progressive. Nevertheless, a closer examination of the Mediterranean data reveals significant and specific regional patterns in vegetation succession, reflecting local intrinsic properties. Therefore, local particularities and the resilience of Iberian Mediterranean vegetation must also be taken into account to explain some apparent contradictions (Carrión, 2001, Carrión et al., 2010, this issue).

It can be summarized that Pleistocene palaeobotanical data for the Iberian Peninsula can be explained by a peculiar confluence of controls. Primarily, they result from a physicalenvironment conditioning, but then, they are also influenced by orbital and suborbital forcings.

\section{2.- Generic extinctions}


The Pleistocene involves genus and species extinction in the Iberian Peninsula, as with other regions of Europe, although certainly affecting less taxa and displaying some peninsular-specific asynchronies in respect to the rest of the continent (Postigo et al., 2007). Based on a database by Postigo et al. (2009) of the Cenozoic extinction, Carrión and Fernández (2009) have calculated the extinction rates of Iberian vascular plants during the last $65 \mathrm{Ma}$, concluding that, the Quaternary (13.29 taxa/Ma) is the period with highest phytodiversity loss, even higher than the Oligocene (10.67 taxa/Ma). Interestingly, the major biotic crisis is not indicated during the PlioPleistocene but rather at the Early-Middle Pleistocene transition, probably associated with the beginning of the $100 \mathrm{ka}$ climatic cyclicity and a general cooling trend. This topic is widely discussed by Postigo et al. (2010, this issue). It is, nevertheless, essential to note that the Pleistocene extinctions are but a small sample of the longer-term disappearance trend that affected Palaeotropical and Arctotertiary plant species ever since the Eocene and with special strength since the Neogene.

Some genera, such as Engelhardtia, disappeared early during the Pleistocene, soon after 1.1 Ma, because it is still present in Bòbila Ordis sequence but absent afterwards. In other cases, the biochronological distribution through the Quaternary is poorly known, like in the case of Aesculus, which is an insect-pollinated tree, and therefore is always under-represented in pollen spectra. It was found, however, in fossil wood in Cal Guardiola (Postigo et al., 2007) during the Early-Middle Pleistocene transition. The case of Parrotia is also interesting. Its pollen morphology, not well known among palynologists due of its poor frequency, is illustrated in Leroy (2007) and Binka et al. (2003). In the Early Pleistocene samples, its occurrence is regular and sometimes reaches significant percentages (up to $9 \%$ in Bòbila Ordis; Leroy, 2008). It is not recorded in Middle Pleistocene sites. However, Parrotia is known in Northern Europe up to the Holsteinian (Binka et al., 2003); therefore it should also have maintained itself in southern Europe, including Iberia, in favourable locations until that time at least. It is therefore uncertain 
whether Parrotia disappeared from the Iberian Peninsula during the Early Pleistocene or later, and why. Its distribution may have been reducing progressively along the Quaternary dry spells, as currently, Parrotia persica is limited to the coastal area south of the Caspian Sea and to the Caucasus up to $1500 \mathrm{~m}$ altitude, where this deciduous tree lives in a mild and humid climate all the year (Davis et al., 1972).

During the Early Pleistocene, the pollen grain of Ulmus should be considered under the taxon Ulmus-Zelkova as the two genera were present as demonstrated in the leaf flora of the site of Incarcal at Crespià (Roiron, 1983) where Zelkova crenata was identified. In the late Early Pleistocene (or later) Zelkova disappeared from Iberia. The precise timing remains unknown, but the last certain appearance is in the sequence of Crespià (unprecised moment in between 2.1 and $1.6 \mathrm{Ma})$.

Other Tertiary taxa that disappeared later in the Quaternary occur in the palynoflora of the Iberian sites, more or less frequently: Eucommia (Garraf 1, Tres Pins, Bòbila Ordis), Cathaya (Garraf 1, Tres Pins, Bòbila Ordis), Liquidambar (Garraf 1, Tres Pins), Nyssa (Garraf 1, Tres Pins), Symplocos (Garraf 1, Tres Pins, Bòbila Ordis) and Parthenocissus (Tres Pins, Bòbila Ordis) (Table 3). Tsuga, Carya and Taxodiaceae are present until the end of the Early Pleistocene. Pterocarya is still present during the Early (Tres Pins: Leroy, 1997, Crespià: Villalta and Vicente, 1972, Roiron, 1983, and Banyoles: Julià and Suc, 1980, Leroy, 1987) and Middle Pleistocene (MIS 11 or Holsteinian) in marine core MD01-2447 offshore NW Iberia (Desprat et al., 2005).

Palaeogeographical models for Cedrus are subject of controversy. Its pollen is frequent in a variety of the sediments of the Iberian Pleistocene, and, while long-distance pollen transport from northern African locations is shown even today (Magri and Parra, 2002), the possibility that local populations of Cedrus survived in the Iberian Peninsula up to the Lateglacial or thereafter cannot be ruled out, like profusely discussed by Postigo et al. (2010, this issue). The abundance 
of Cedrus pollen in the Early Pleistocene is certainly supporting its occurrence in the lberian Peninsula (Joannin, 2007). In fact, the Cedrus-Abies assemblages are probably related to a relatively high level of precipitation not only in altitude but also in the lowlands, where the ratio Asteraceae liguliflorae to Artemisia is higher during the Early than during the Late Pleistocene.

The case of Picea is pertinent to northern Iberia during the Late Pleistocene. While today it is extinct, the pollen sequence of Area Longa (Gómez-Orellana et al., 2007) and charcoal analyses from three archaeological sites located on the Cantabrian shoreline (La Pila and Santa Catalina caves, and Peña del Perro rockshelter: see Table 1) yielded evidence of Picea, even until the Early Holocene (Uzquiano, 1995). Picea pollen is no longer recorded: in the Area Longa sequence, from AREL-6e zone (1460 cm depth) upwards, during the Lower Pleniglacial, while anthracological data show a continuous but decreasing presence between 12.5-11.7 uncal. ka BP from La Pila cave (see Fig. 1). Santa Catalina cave has one charcoal fragment of Picea in bed 27 (12.7 uncal. ka BP) and La Peña del Perro rockshelter another one in bed 2A, dated at 10.1 uncal. ka BP, so in the Early Holocene. All these data suggest the maintenance of Picea relict clusters along different areas of the Cantabrian shoreline (Uzquiano, 1998). The main cause of its disappearance is difficult to understand (Postigo et al., 2009), and it is for other taxa like Platanus (García-Antón et al., 1990), which nevertheless may have disappeared due to natural causes (Postigo et al., 2008).

In the leaf flora of Incarcal at Crespià, Laurus nobilis and L. canariensis have also been noted (Roiron, 1983). Their pollen grains do not preserve well, neither survive well pollen extraction; therefore we have no record of any change in their area of distribution over time.

\section{3.- Survival of temperate, Mediterranean, and Ibero-North African woody species}

Ever since the first investigations in southern Europe (Beug, 1968, Van Campo, 1969, Jalut et al., 1975), the composition, structure and location of glacial refugia of temperate tree species has 
been a subject of devoted research. Using pollen records, Huntley and Birks (1983) hypothesized the prevalence of migrational patterns of tree expansions from glacial refugia, which would have been largely located in the eastern Mediterranean. A similar perspective was adopted by Bennett et al. (1991), although these last authors predicted that this situation could change as new data were acquired. In a seminal work, Costa Tenorio et al. (1990) had already suggested that lowlands and mid-altitude mountain regions of lberia could have served as refugia for tree taxa. These authors based their speculation in the current distribution of tree species, and in the observation that Lateglacial forest developments were relatively rapid as observed in pollen diagrams, an approach also adopted by Willis (1994) in the Balkans.

For the Iberian Peninsula, Figure 13 drafts the available evidences for broad-leaf and evergreen trees and shrubs, as well as the Mediterranean sclerophyllous elements, during MIS 4, MIS 3 and MIS 2. The evidences (the data themselves) for the two first stages are sparse and those maps should be taken, more like accounts of findings, than as distribution maps. Yet, they should not be taken to infer distribution changes from the Early to Middle, then to the Late Pleistocene. Some patterns can be notwithstanding assessed. During the coldest episodes of the MIS 3 and MIS 2, the occurrence of Ibero-North African xerothermic scrub is noticeable in coastal Murcia, Málaga and the southernmost extreme in the Gibraltar Peninsula. But the most striking feature is the broad occurrence of tree populations throughout the whole region, including continental territories. Genera like Corylus, Quercus, Fraxinus, Alnus, Betula, Castanea, and Fagus, among others, are common components of the Pleistocene pollen assemblages not only in the south, but also in the northwest (i.e. Gómez-Orellana et al., 2007), Cantabrian Mountains and Central Iberia (Uzquiano, 1992b, López-Merino et al., 2008), Pyrenees (Montserrat, 1992, González-Sampériz et al., 2005, 2006) pre-Pyrenees (Pérez-Obiol and Julià, 1994, GonzálezSampériz et al., 2003, 2005), north-eastern areas (Ros Mora, 1987, Burjachs and Julià, 1994, Burjachs and Allué, 2003), Central Ebro Basin (Valero-Garcés et al., 2000a, 2000b, González- 
Sampériz, 2004), Iberian Range and Central system (Peñalba, 1994, Uzquiano, unpublished data).

It seems, therefore, that the Iberian Peninsula was covered by patches of vegetation types with more or less abundant woody plant taxa during the Pleistocene, including relicts from the Middle or the Late Pleistocene (i.e. Juglans, Carpinus, Fagus, Castanea, Celtis, and Platanus: Postigo et al., 2008) up to present (i.e. Prunus lusitanica: Pulido et al., 2008, Calleja et al., 2009). It is also worth mentioning (Table 1, Fig. 13) that Iberian refugia could have been at relatively high-altitude in mountain areas. This is confirmed in some outstanding pollen records such as the site of Siles, at 1400 m a.s.l., in the Segura Mountains of southern Spain (Carrión, 2002a).

It cannot be sufficiently stressed that the location of Iberian glacial refugia is not limited to the southern territories, because it follows that the conventional picture of long-distance migration since southern coastal areas is loosing its explanatory power. Data are now converging to depict a different picture in which a mosaic of forests, savannahs, and sparse stands of small populations of woody plant species scattered in multiple regions would have taken the main role (Carrión et al., 2008). Phylogeographical models based on the genetic structure of current populations (Taberlet et al., 1998, Hewitt, 1999, Olalde et al., 2002, Petit et al., 2002, Provan and Bennett, 2008, Bhagwat and Willis, 2008), and climate modelling of potential refuge areas (Benito Garzón et al., 2006, 2007, Leroy and Arpe, 2007, Médail and Diadema, 2009, Tzedakis, 2009, see Rodríguez-Sánchez et al., 2010, this issue, for further detail), support this view and postulates, in addition, that the most continental and northern Peninsula served yet as an area of secondary refugia and/or microrefugia during diverse unfavourable regional environmental conditions.

Concerning this topic, we are only starting to build methodological and conceptual connections between ecology, palaeoecology and evolution. It bears emphasis that changes in 
atmospheric $\mathrm{CO}_{2}$ content may also have added to the effects of aridity in vegetation composition and fluctuations. The amplitude of millennial-scale changes in $\mathrm{CO}_{2}$ has been traditionally considered too small to imply any really relevant contribution in Mediterranean vegetation changes (Stauffer et al., 1998, Tzedakis et al., 2003). However, experiments on Ambrosia artemisiaefolia in greenhouses have shown that when $\mathrm{CO}_{2}$ is low, the pollen production is low too (Ziska and Caulfield, 2000). Low $\mathrm{CO}_{2}$ during glacial times might have been an important factor for the underestimation of the number of trees surviving harsh times in sheltered positions (Leroy, 2007). Owing to this under-representation of trees in the pollen record, the interpretation of several pollen diagrams during the strong glacial times of the Middle and the Late Pleistocene could therefore be revisited.

This change of paradigm is also stimulated by neontological advances in biogeography. Médail and Diadema (2009) infer the putative location of plant refugia in the Mediterranean Basin on the basis of current chorological data. They show that a robust biogeographical congruence exists between the plausible location of refuge areas and the Mediterranean regions with highest biodiversity values. Refugia would fall entirely within areas with an endemism rate $>10 \%$. At this point, and after the palaeobotanical data showed in Fig. 13 for the whole lberian territory, it must be remembered that the Iberian peninsula has an endemicity index between 25 and $30 \%$ (Castroviejo, 2002, Sainz-Ollero and Moreno, 2002), which would confirm that the history of the Pleistocene Iberian flora is, at least partially, the result of a particular geographical position. So, Iberia represents a Quaternary hotspot, as it is still crucial in today's context of Global Change.

Gaining further detail in the interpretation of the controls of the distribution of glacial refugia as seen in Fig. 13, is challenging. The chronological control and spatial coverage are clearly insufficient to achieve that task. Climatic heterogeneity and climate change itself may have been important. Thus, in the knowledge that aridity of the southeastern is a feature ever since the late Miocene and Pliocene (Carrión et al., 2009, in press), the survival of Ibero-North African 
xerothermic scrub in the coastal territories is not surprising. Other southeastern pollen records, especially inland, even marine cores, fail to show these taxa (such as Maytenus, Periploca, and Withania), most likely because they are strictly insect-pollinated and their dispersal and input on the sediment of open-air sites is extremely deficient, as shown by Carrión (2002b). But they are present in cave minerogenic sediment and coprolites under depositional circumstances suitable for biotic transport (Carrión et al., 2008).

The integration of genetic and palaeobotanical data in other regions of southern Europe (i.e. Magri, 2008) has provided similar conclusions to this paper. What this involves is more complexity in the patterns of postglacial development. This complex network of glacial populations may have brought about competition, facilitation, and genetic flow to overlap with migrational patterns and bottlenecks as historical constraints for the modern genetic and distributional pathways. A note of singularity: in comparison with other Mediterranean peninsulas (Magri and Sadori, 2005, Tzedakis, 2009), Iberia was, doubtless, particularly suitable for the survival of sclerophyllous elements of any kind during glacial stages of the Pleistocene. Overall, and dealing with plant species, the Iberian Peninsula is more a land of survival than extinction for the whole Cenozoic (Postigo et al., 2009, this issue), but especially for the Pleistocene.

\section{Acknowledgements}

This research work has been funded by the national projects CGL-2009-6988 (IBERVELD), CGL2009-07992 (DINAMO), CGL-2006-2956-BOS, CGL2006-13327-C04-01 (CALIBRE), CGL200806005/BOS, GRACCIE-CONSOLIDER INGENIO 2010 (CSD2007-00067) and PALEODIVERSITAS network from Fundación Séneca. We thank F. Burjachs for unpublished information on the Early Pleistocene section of Atapuerca. We also thank all Iberian palaeoecologists for years of generous and intensive work. 


\section{References}

Agustí, J., Julià, R., 1990. Palaeoclimatic inferences from the Plio-Pleistocene continental sequence of the Guadix-Baza basin (Spain). Paleobiologie Continentale 17, 269-279.

Agustí, B., Alcalde, G., Burjachs, F., Juan-Muns, N., Oller, J., Ros, M.T., Rueda, J.M., 1987. El yacimiento del Paleolítico Medio de la Cueva 120 (Garrotas, Catalunya). Primeros resultados. Cuaternario y Geomorfología 1, 1-13.

Alcalde-Olivares, C., Gómez Manzaneque, F., Postigo Mijarra, J.M., Sanz, E., Menéndez-Pidal, I. 2003. Pinus sylvestris L. en el Pleistoceno superior del Duero (Vega Cintora, Soria, España). Rev. Cuaternario y Geomorfología, 17(1-2), 21-28.

Allen, J., Huntley, B., 2000. Weichselian palynological records from southern Europe: correlation and chronology. Quaternary International 73, 111-125.

Allen, J.R.M., Huntley, B., Watts, W.A., 1996. The vegetation and climate of northwest lberia over the last 14,000 yr. Journal Quaternary Science 11, 125-147.

Allué, E., 2002. Dinámica de la vegetación y explotación del combustible leñoso durante el Pleistoceno Superior y el Holoceno del noreste de la Península Ibérica a partir del análisis antracológico. Ph.D. Thesis, Universitat Rovira i Virgili, Tarragona, 328 pp.

Andrade, M.M., 1944. Estudio polínico de algumas formaçoes turfolignitosas portuguesas. Publ. Mus. Lab. Min. Geol. Fac. Ciên. Porto 37(2), 5-11.

Antunes, M.T., Mein, P., Nascimento, A., Pais, J., 1986. Le gisement pleistocène de Morgandinho, en Algarve. Ciências da Terra 8, 9-22.

Arrizabalaga, A., Iriarte, M.J., 2005. Irikaitz (Zestoa, País Vasco): estudio preliminar del paleolítico inferior en el sondeo. O Paleolítico: actas do IV Congresso de Arqueologia Peninsular, pp. 267-276. 
Arrizabalaga, A., Iriarte, M.J., Ruiz-Alonso, M., 2003. El Yacimiento arqueológico de Irikaitz (Zestoa-Gipuzkoa). Contextualización arqueobotánica y en el marco del Paleolítico Inferior Vasco. Actas XI Reunión AEQUA. Oviedo, pp. 211-218.

Arrizabalaga, A., Altuna, J., Areso, P., Falgueres, C., Iriarte, M.J., Mariezkurrena, K., Pemán, E., Ruiz-Alonso, M., Tarriño, A., Uriz, A., Vallderdu, J., 2004. Retorno a Lezetxiki (Arrasate, País Vasco): nuevas perspectivas de la investigación. In: Santonja, M., Pérez-González, A., Machado, M.J. (Eds.), Geoarqueología y conservación del patrimonio, ADEMA, España, pp. 20-26.

Aubry, T., Brugal, J.Ph., Chauvière, F.X., Figueiral, I., Moura, M.H., Plisson, H., 2001. Modalités d'occupations au Paléolithique supérieur dans la grotte de Buraca Escura (Redinha, Pombal, Portugal). Rev. Portuguesa de Arqueologia 4(2), 19-46.

Aura, E., Carrión, Y., Estrelles, E., Pérez, G., 2005. Plant economy of hunter-gatherer groups at the end of the last Ice Age: plant macrorremains from the cave of Sta. Maira (Alacant, Spain), ca 12000-9000 BP. Vegetation History and Archaeobotany 14, 542-550.

Aura, E., Jordá, J.F., Pérez, M., Rodrigo, M.J., Badal, E., Guillem, G., 2002. The far south: the Pleistocene-Holocene transition in Nerja cave (Andalucía, Spain). Quaternary International 93/94, 19-30.

Badal, E., 1991. La vegetación durante el Paleolítico Superior en el País Valenciano y Andalucía: Resultados antracológicos. In: Arqueología medioambiental a través de los macrorrestos vegetales. Madrid. Ayuntamiento de Madrid. Área de Medioambiente. Aula de Ecología .

Badal, E., Carrión, J.S., 2001. Del glaciar al interglaciar: los paisajes vegetales a partir de los restos carbonizados hallados en las cuevas de Alicante. In: Villaverde, V. (Ed.), De neardenthales a cromañones. El inicio del doblamiento en las tierras valencianas. Universitat de Valencia, pp. 21-44. 
Badal, E., Bonet, H., Collado, E., Fabado, J., Fuentes, M., Izquierdo, I., Mata, C., Moreno, A., Ntinou, M., Quixal, D., Ripollès, P.P., Soria, L., 2008. Lo real y lo imaginario. El proyecto Hum2004-04939 sobre la flora en el mundo Ibérico. In: Rovira, S., García-Heras, M., Gener, M., Montero, I. (Eds.), Actas VII Congreso Ibérico de Arqueometría, Madrid, pp. 144-157.

Baillie, M.G.L., 1991. Suck in and smear - two related chronological problems for the 90s. Journal of Theoretical Archaeology 2, 12-16.

Benito Garzón, M., Blazek, R., Neteler, M., Sánchez de Dios, R., Sáinz Ollero, H., Furlanello, C., 2006. Predicting habitat suitability with machine learning models: The potential area of Pinus sylvestris L. in the Iberian Peninsula. Ecological Modelling 197, 383-393.

Benito Garzón, M., Sánchez de Dios, R., Sáinz Ollero, H. 2007. Predictive modelling of tree species distributions on the Iberian Peninsula during the Last Glacial Maximum and MidHolocene. Ecography 30, 120-134.

Bennett, K., Tzedakis, P.C., Willis, K., 1991. Quaternary refugia of north European trees. Journal of Biogeography 18, 103-115.

Bergadà, M.M., Burjachs, F., Fullola, J.M., 1999. Evolution paléoenvironnementale de 14.500 a 10.000 BP. dans les prépyrénées catalans: La grotte du Parco (Alòs de Balaguer, Lleida, Espagne). L'Anthropologie 103, 249-264.

Berger, G.W., Pérez González, A., Carbonell, E., Arsuaga, J.L., Bermúdez de Castro, J.M., Ku, T.L., 2008. Luminescence chronology of cave sediments at the Atapuerca paleoanthropological site, Spain. Journal of Human Evolution 55, 300-311.

Beug, H.J. ,1968. Probleme der Vegetationsgeschichte in Südeuropa. Ber. Dtch. Bot. Ges. Bd. 80, H.10, 682-689. 
Binka, K., Nitychoruk, J., Dzierzek, J., 2003. Parrotia persica C.A.M. (Persian witch hazel, Persian ironwood) in the Mazovian (Holsteinian) Interglacial of Poland. Grana 42, 227-233.

Blanco-Castro, E., Casado, M., Costa, M., Escribano, R., García-Antón, M., Génova, M., Gómez, A., Moreno, J., Morla, C., Regato, P., Sainz Ollero, H., 1997. Los bosques ibéricos. Una interpretación geobotánica. Barcelona: Planeta, 572.

Boessenkool, K.P., Van Gelder, M.J., Brinkhuis, H., Troelstra, S., 2001. Distribution of organicwalled dinoflagellate cysts in surface sediments from transects across the Polar Front offshore southeast Greenland. Journal of Quaternary Science 16, 661-666.

Bout-Roumazeilles, V., Combourieu-Nebout, N., Peyron, O., Cortijo, E., Landais, A., MassonDelmotte, V., 2007. Connection between South Mediterranean climate and North African atmospheric circulation during the last 50,000 yr BP North Atlantic cold events. Quaternary Science Reviews 26, 3197-3215.

Boyer-Klein, A., 1976. Análisis polinico de la cueva de Tito Bustillo (Asturias). In: Moure Romanillo, A., Cano Herrera, M. (Eds.), Excavaciones en la cueva de Tito Bustillo Trabajos de 1975. Inst. Estud. Asturianos. Asturias, pp. 203-206.

Boyer-Klein, A., 1981. Análisis palinológico del Rascaño. In: González Echegaray, J., Barandiarán Maestu, I. (Eds.), El Paleolítico Superior en la cueva del Rascaño (Santander). Ministerio de Cultura. Santander, pp. 217-220.

Boyer-Klein, A., 1984. Analyses Polliniques cantabriques au Tardiglaciaire. Revue de Paléobiologie, vol. spécial, 33-39.

Boyer-Klein, A., 1985. Analyse Pollinique de la Grotte d’Erralla. Munibe 37: 45-48.

Boyer-Klein, A., 1988. Analyses polliniques au Tardiglaciaire dans le Nord de l' Espagne: au sujet des Dryas I, II, III. Actas de Palinología (VI Simposio), Salamanca, pp. 276-283. 
Boyer-Klein, A., 1989. Análisis polínico de la cueva de Zatoya. In: Barandiarán, I., Cava, A. (Eds.), El yacimiento prehistórico de Zatoya. Euskonews \& Media. Pamplona, pp. 231-235.

Bragwat, S., Willis, K., 2008. Species persistence in northerly glacial refugia of Europe: a matter of chance or biogeographical traits? Journal of Biogeography 35, 464-482.

Burjachs, F., 1990. Palinologia dels dòlmens de l'Alt Empordà i dels depòsits quaternaris de la cova de l'Arbreda (Serinyà, Pla de l'Estany) i del Pla de l'Estany (Olot, Garrotxa). Evolució del paisatge vegetal i del clima des de fa més de 140.000 anys al N.E. de la Península Ibèrica. Ph.D. Thesis, Universitat Autònoma de Barcelona, Bellaterra, 324 pp.

Burjachs, F., 1993. Paleopalinología del Paleolítico superior de la Cova de L'Arbreda (Serinyà, Catalunya). In: Fumanal, M.P., Bernabeu, J. (Eds.), Estudios sobre Cuaternario. Asociación Española para el Estudio del Cuaternario. Valencia, pp. 149-157.

Burjachs, F., 1994. Palynology of the Late Pleistocene and Holocene of the North-East lberian Peninsula: Pla de l'Estany. Historical Biology 9, 17-33.

Burjachs, F., 2001. Paleoecología del Homo antecessor. Palinología de las unidades TD5, 6 y 7 de la 'Gran Dolina' de Atapuerca (Burgos, Spain). In: Moreno Grau, S., Elvira Rendueles, B., Moreno Angosto, J.M. (Eds.), XIII Simposio de la Asociación de Palinólogos en Lengua Española (APLE). Universidad Politécnica de Cartagena, Servicio de Publicaciones. Cartagena, pp. 365-372.

Burjachs, F., Allué, E., 2003. Palaeoclimatic evolution during the last glacial cycle at the NE of the Iberian Peninsula. In: Ruiz-Zapata, B., Dorado, M., Valdeolmillos, A., Gil-García, M.J., Bardají, T., Bustamante, I., Martínez, I. (Eds.), Quaternary Climatic Changes and Environmental Crises in the Mediterranean Region. Ministerio de Ciencia y Tecnología and INQUA. Alcalá de Henares, pp. 191-200. 
Burjachs, F., Julià, R., 1994. Abrupt climate changes during the last glaciation based on pollen analysis of the Abric Romani, Catalonia, Spain. Quaternary Research 42, 308-315.

Burjachs, F., Comín, F., Rodó, X., 1996. Gallocanta: ejemplo de secuencia palinológica en una laguna efímera. In: Ruiz-Zapata, B. (Ed.), Estudios Palinológicos. Servicios de Publicaciones de la Universidad de Alcalá, Alcalá de Henares, pp. 25-29.

Cacho, C., Fumanal, P., Pérez Ripoll, M., Martínez Valle, R., Uzquiano, P., Arnanz, A.M., Sánchez Marco, A., Sevilla, P., Morales, A., Roselló, E., Garralda, M.D., García Carrillo, M., 1995. El Tossal de la Roca (Vall d'Alcalá, Alicante). Reconstrucción Paleoambiental y cultural de la transición del Tardiglaciar al Holoceno inicial. Recerques del Museu d’Alcoi 4, 11-101.

Calleja, J.A., Benito Garzón, M., Sainz-Ollero, H. 2009. A Quaternary perspective on the conservation prospects of the Terciary relict tree Prunus lusitanica L. Journal of Biogeography 36, 487-498.

Capel Molina, J.J., 1981. Los climas de España. Oikos-Tau S.A. Ediciones. Barcelona, 429 pp.

Carrión, J.S., 1992a. Late quaternary pollen sequence from Carihuela Cave, Southern Spain. Review of Palaeobotany and Palynology 71: 37-77.

Carrión, J.S., 1992b. A palaeoecological study in the western Mediterranean area. The Upper Pleistocene pollen record from Cova Beneito (Alicante, Spain). Palaeogeography, Palaeoclimatology, Palaeoecology 92: 1-14.

Carrión, J.S., 2001. Dialectic with climatic interpretations of Late-Quaternary vegetation history in Mediterranean Spain. Journal of Mediterranean Ecology 2, 145-156.

Carrión, J.S., 2002a. Patterns and processes of Late Quaternary environmental change in a montane region of southwestern Europe. Quaternary Science Review 21, 2047-2066. 
Carrión, J.S., 2002b. A taphonomic study of modern pollen assemblages from dung and surface sediments in arid environments of Spain. Review of Palaeobotany and Palynology 120, 217-232.

Carrión, J.S., Dupré, M., 1996. Late Quaternary vegetational history at Navarrés, Eastern Spain. A two core approach. New Phytologist 134: 177-191.

Carrión, J.S., Dupré, M., Fumanal, M.P., Montes, R., 1995. A palaeoenvironmental study in Semiarid Southeastern Spain: the Palynological and Sedimentological Sequence at Perneras Cave (Lorca, Murcia). Journal of Archaeological Science 22, 355-367.

Carrión, J.S., Fernández, S., 2009. Taxonomic depletions and ecological disruption of the lberian flora over 65 million years. Journall of Biogeography 36, 2022-2024.

Carrión, J.S., Fernández, S., González-Sampériz, P., Gil-Romera, G., Badal, E., Carrión-Marco, Y., López-Merino, L., López-Sáez, J.A., Burjachs, F.,in revision, this issue. Expected trends and surprises in the Lateglacial and Holocene vegetation history of the Iberian Peninsula and Balearic Islands. Review of Palaeobotany and Palynology.

Carrión, J.S., Fernández, S., González-Sampériz, P., Leroy, S., Bailey, G. N., López-Sáez J.A., Burjachs, F., Gil-Romera, G., García-Antón, M., Gil-García, M.J., Parra, I., Santos, L., López-Garcia, P., YII, R., Dupré, M., 2009a. Quaternary pollen analysis in the Iberian Peninsula: the value of negative results. Internet Archaeology. http://intarch.ac.uk/journal/issue25/5/toc.html

Carrión, J.S., Fernández, S., Jiménez-Moreno, G., Fauquette, S., Gil-Romera, G., GonzálezSampériz, P., Finlayson, C., 2009b. The historical origin of aridity and vegetation degradation in southeastern Spain. Journal of Arid Environments (in press).

Carrión, J.S., Finlayson, C., Fernández, S., Finlayson, G., Allué, E., López-Sáez, J.A., LópezGarcía, P., Gil-Romera, G., Bailey, G., González-Sampériz, P., 2008. A coastal reservoir of 
biodiversity for Late Pleistocene human populations: palaeoecological investigations in Gorham's Cave (Gibraltar) in the context of Iberian Peninsula. Quaternary Science Reviews 27, 2118-2135.

Carrión, J.S., Munuera, M., 1997. Late Pleistocene paleoenvironmental change in Eastern Spain: new pollen-analytical data from Cova Beneito (Alicante). Palaeogeography, Palaeoclimatology, Palaeoecology 128, 287-299.

Carrión, J.S., Munuera, M., Navarro, C., 1998. Palaeonvironmental reconstructions of cave sediments on the basis palynology: an example from Carihuela Cave (Granada). Review of Palaeobotany and Palynology 99, 17-31.

Carrión, J.S., Munuera, M., Navarro, C., Burjachs, F., Dupré, M., Walker, M. J., 1999. The palaeoecological potential of pollen records in caves: the case of Mediterranean Spain. Quaternary Science Reviews 18, 1061-1073.

Carrión, J.S., Munuera, M., Navarro, C., Sáez, F., 2000. Paleoclimas e historia de la vegetación cuaternaria en España a través del análisis polínico. Viejas falacias y nuevos paradigmas. Complutum 11, 115-142.

Carrión, J.S., Riquelme, J.A., Navarro, C., Munuera, M., 2001. Pollen in hyaena coprolites reflects late glacial landscape in Southern Spain. Palaeogeography, Palaeoclimatology, Palaeoecology 176, 193-205.

Carrión, J.S., Sánchez-Gómez, P., 1992. Palynological data in support of the survival of Walnut (Juglans regia L.) in the western Mediterranean area during last glacial times. Journal of Biogeogeography 19, 623-630.

Carrión, J.S., Scott, L., Arribas, A., Fuentes, N., Gil-Romera, G., Montoya, E., 2007. Pleistocene landscapes in central Iberia inferred from pollen analysis of hyena coprolites. Journal of Quaternary Science 22, 191-202. 
Carrión, J.S., van Geel, B., 1999. Fine-resolution Upper Weichselian and Holocene palynological record fron Navarrés (Valencia, Spain) and a discussion about factors of Mediterranean forest sucession. Review Palaeobotany and Palynology 106, 209-236.

Carrión, J.S., YII, E.I., Walker, M.J., Legaz, A.J., Chain, C., Lopez, A., 2003. Glacial refugia of temperate, Mediterranean and Ibero-North African flora in south-eastern Spain: new evidence from cave pollen at two Neanderthal man sites. Global Ecology and Biogeography 12, 119-129.

Carrión-Marco, Y., 2005. La vegetación mediterránea y atlantica de la Peninsula Ibérica: nuevas secuencias antracológicas. Trabajos Varios de S.I.P. (Servicio de Investigación 776 Prehistórica) 104. Diputación Provincial de Valencia, Valencia. 314 pp.

Castroviejo, S., 2002. Riqueza florística de la península Ibérica e Islas Baleares. El proyecto "Flora Ibérica". In: Pineda, F.D., de Miguel, J.M., Casado, M.A., Montalvo, J. (Eds.), La Diversidad Biológica de España. Pearson Educación. Madrid, pp. 167-174.

Cattani, L., García-Antón, M., Renault-Miskovsky, J., 1994. The Early and Middle Pleistocene in the circum-mediterranean region. Attempts and results of archaeo-palynological correlations. AASP Contributions Series 29, 27-52.

Cita, M.B., Capraro, L., Ciaranfi, N., Di Stefano, E., Lirer, F., Maiorano, P., Marino, M., Raffi, I., Rio, D., Sprovieri, R., Stefanelli, S., Vai, G.B. 2008. The Calabrian stage redefined. Episodes 31 (4), 408-419.

Clark, P.U., Archer, D., Pollard, D., Blum, J.D., Rial, J.A., Brovkin, V., Mix, A.C., Pisias, N.G., Roy, M., 2006. The middle Pleistocene transition: characteristics, mechanisms, and implications for long-term changes in atmospheric pCO2. Quaternary Science Reviews 25, 3150-3184. 
Claussen, M., 2008. Introduction to climate forcing and climate feedbacks. In: The climate of past interglacials (Sirocko, F., Claussen, M., Sánchez-Goñi, M.F., Litt, T., eds.), Elsevier, Amsterdam, pp. 3-12.

Claussen, M., Berger, A., Held, H., 2008. A survey of hypotheses for the 100-kyr cycle. In: The climate of past interglacials (Sirocko, F., Claussen, M., Sánchez-Goñi, M.F., Litt, T., eds.), Elsevier, Amsterdam, pp. 29-36.

Combourieu-Nebout, N., Londeix, L., Baudin, F., Turon, JL., von Grafenstein, R., Zahn, R., 1999. Quaternary Marine and Continental Paleoenvironments in the Western Mediterranean (Site 976, Alboran Sea): Palynological Evidence. In: Zahn, R., Comas, M.C., Klaus, A. (Eds.), Proceedings of the Ocean Drilling Program, Scientific Results 161, 457-468.

Combourieu-Nebout, N., Turón, J.L., Zahn, R., Capotondi, L., Londeix, L., Pahnke, K., 2002. Enhanced aridity and atmospheric high-presure stability over ther western Mediterranean during the North Atlantic cold events of the past 50 k.y. Geological Society of America 30(10), 863-866.

Combourieu-Nebout, N., Peyron, O., Dormoy, I., 2009. Rapid climatic variability in the west Mediterranean during the last 25000 years from high resolution pollen data. Climate of the Past Discussions 5, 671-707.

Costa Tenorio, M., García-Antón, M., Morla Juaristi, C., Sainz-Ollero, H., 1990. Evolución de los bosques de la Península Ibérica: una interpretación basada en datos paleobiogeográficos. Ecología, Fuera de serie 1, 31-58.

Cross, J., Perez Obiol, R., Roure, J.M., 1986. Primeres dades sobre la vegetació i el clima del Quaternari Mitjà a Olot (NE Península Ibérica). Collect. Bot. 16(2), 365-369.

Davis, O.K., 1994. The correlation of summer precipitation in the southwestern U.S.A. with isotopic records of solar activity during the Medieval Warm Period. Climate Change 26, 271-287. 
Davis, P.H., Harper, P.C., Hedge, I.C., 1972. Plant life of south-west Asia. Springer on New York Botanical Garden Press, New York.

De Deckker, P., Geurts, M., Julià, R., 1979. Seasonal rythmites from a Lower Pleistocene lake in northeastern Spain. Palaeogeography, Palaeoclimatology, Palaeoecology 26, 43-71.

Desprat, S., Sánchez-Goñi, M.F., Turon, J.L., McManus, J.F., Loutre, M.F., Duprat, J., Malaize, B., Peyron, O., Peypouquet, J.P., 2005. Is vegetation responsible for glacial inception during periods of muted insolation changes? Quaternary Science Reviews 24, 1361-1374.

Desprat, S., Sánchez-Goñi, M.F., Turon, J.L., Duprat, J., Malaize, B., Peypouquet, J.P., 2006. Climatic variability of Marine Isotope Stage 7: direct land-sea-ice correlation from a multiproxy analysis of a north-western Iberian margin deep-sea core. Quaternary Science Reviews 25, 1010-1026.

Desprat, S., Sánchez-Goñi, M.F., Naughton, F., Turon, J.L., Duprat, J., Malaize, B., Cortijo, E., Peypouquet, J.P., 2007. Climate variability of the last five isotopic interglacials from direct land-sea ice correlation. In: Sirocko, F., Claussen, M., Sánchez-Goñi, M.F., Litt, T. (Eds.), The climate of past interglacials. Elsevier 7, 277-288.

Diniz, F., 1972. Notas palinológicas sobre formações ceno-antropozóicas portuguesas. Boletim do Museu e Laboratório Mineralógico e Geológico da Faculdade de Ciências de Lisboa 13(1), 83-95.

Dupré, M., 1988. Palinología y paleoambiente. Ph.D. Thesis, Nuevos datos españoles. Servicio de Investigación Prehistórica. Diputación provincial de Valencia. Serie de Trabajos Varios 84, Valencia.

Dupré, M., Fumanal, M.P., Martínez Gallego, J., Pérez-Obiol, R., Roure, J.M., Usera, J., 1996. The Laguna de San Benito (Valencia, Spain): palaeoenvironmental reconstruction of an endorheic system. Quaternaire 7(4), 177-186. 
Elhaï, H., 1966. Deux gisements du Quaternaire moyen. Bruges (Sud-Ouest de France). Bañolas (Catalogne). Bulletin de l'Association Française de l'Etude du Quaternaire 6, 69-78.

Fauquette, S., Guiot, J., Suc, J.P., 1998a. A method for climatic reconstruction of the Mediterranean Pliocene using pollen data. Palaeogeography, Palaeoclimatology, Palaeoecology 144(1-2), 183-201.

Fauquette, S., Quézel, P., Guiot, J., Suc, J.P., 1998b. Signification bioclimatique de taxons-guides du Pliocène méditerranéen. Geobios 31(2): 151-169.

Fernández, S., Fuentes, N., Carrión, J.S., González-Sampériz, P., Montoya, E., Gil, G., VegaToscano, G., Riquelme, J.A., 2007. The Holocene and Late Pleistocene pollen sequence of Carihuela Cave, southern Spain. Geobios 40, 75-90.

Figueiral, I., 1990. Le Nord-Ouest du Portugal et les modifications de l'Ecosystème du Bronze final à l'époque romaine d'après l'analyse anthracologique de sites archéologiques. $\mathrm{PhD}$, University of Montpellier.

Figueiral, I., 1993. Cabeço de Porto Marinho : une approche paléoécologique. Premiers résultats. In: Fumanal, M.P., Bernabeu, J. (Eds.), Estudios sobre Cuaternario. Medios Sedimentarios. Cambios ambientales. Habitat humano. Valencia, pp. 167-172.

Figueiral, I., 1995. Charcoal analysis and the history of Pinus pinaster (cluster pine) in Portugal. Review of Palaeobotany and Palynology 89, 441-454.

Figueiral, I., 1998. O Abrigo da Pena d'Agua (Torres Novas): a contribuição da antracologia. Rev. Portuguesa de Arqueologia 1(2), 73-79.

Figueiral, I., Terral, J.F., 2002. Late Quaternary refugia of mediterranean taxa in the Portuguese Estremadura: charcoal based palaeovegetation and climatic reconstruction. Quaternary Science Reviews 21, 549-558. 
Fletcher, W.J., Sánchez-Goñi, M.F., 2008. Orbital- and sub-orbital-scale climate impacts on vegetation of the western Mediterranean basin over the last 48,000 yr. Quaternary Research 70, 451-464.

Fletcher, W.J., Boski, T., Moura, D., 2007. Palynological evidence for environmental and climatic change in the lower Guadiana valley, Portugal, during the last 13,000 years. The Holocene 17(4), 479-492.

Florschütz, F., Menéndez-Amor, J., Wijmstra, T.A., 1971. Palynology of a thick Quaternary succession in southern Spain. Palaeogeography, Palaeoclimatology, Palaeoecology 10, 233-264.

Follieri, M., Giardini, M., Magri, D., Sadori, L., 1998. Palynostratigraphy of the last glacial period in the volcanic region of Central Italy. Quaternary International 47/48, 3-20.

García-Antón, M., 1995. Pollen analysis of Middle Pleistocene palaeovegetation at Atapuerca. In: Bermúdez, J.M., Arsuaga, J.L., Carbonell, E. (Eds.), Human Evolution in Europe and the Atapuerca evidence. Publicaciones de la Junta de Castilla y León, 1. Valladolid, pp. 147165.

García-Antón, M., 1998. Reconstrucciones de paleovegetación en Atapuerca, según análisis polínicos. In: Aguirre, E. (Ed.), Atapuerca y la evolución humana. Centro de Estudios Ramón Areces. Madrid, pp. 63-71.

García-Antón, M., Sainz-Ollero, H., 1991. Pollen records from the Middle Pleistocene Atapuerca site (Burgos, Spain). Palaeogeography, Palaeoclimatology, Palaeoecology 85, 199-206.

García-Antón, M., Morla Juaristi, C., Sainz Ollero, H., 1990. Consideraciones sobre la presencia de algunos vegetales relictos terciarios durante el Cuaternario en la Península lbérica. Boletín Real Sociedad Española de Historia Natural (Sección Biológica) 86, 95-105. 
García-Antón, M., Maldonado Ruiz, J., Morla Juaristi, C., Sainz-Ollero, H., 2002. Fitogeografía histórica de la Península Ibérica. In: Pineda, F.D., de Miguel, J.M., Casado, M.A., Montalvo, J. (Eds.), La diversidad biológica de España. CYTED. Madrid, pp. 45-63.

Geurts, M., 1977. Premières données à l'étude palynologique des depots calcareux quaternaires en Catalogne. Acta Geológica Hispánica 12, 86-89.

Geurts, M.A., 1979. Approche palynostratigraphique des depots calcareux quaternaires dans la region de Banyoles-Besalú (Catalogne). In: Julià et al. (Ed.), Actas de la IV Reunion del Grupo de trabajo del Cuaternario, Barcelona, pp. 106-116.

Gibbard, P., van Kolfschoten, Th. 2004 The Pleistocene and Holocene epochs. In: Gradstein, F. Ogg, J., Smith, A. (eds) A Geologic Time Scale. Cambridge University Press, Cambridge, pp. 441-452.

Gibert, J., Martínez, B., Caporicci, R., Jiménez, C., Fernández, C., Ribot, F., Soria, F., PérezCuadrado, J.L., Arribas, A., Canals, J., García-Targa, J.M., Iglesias, A., Romero, R., 1988. Resumen de las Investigaciones paleoantropológicas y arqueológicas de Orce (Granada) y Cueva Victoria (Cartagena). COL-PA 42: 11-60.

Gil-García, M.J., Dorado, M., Valdeolmillos, A., Ruiz-Zapata, M.B., 2002. Late-glacial and Holocene palaeoclimatic record from Sierra de Cebollera (northern Iberian Range, Spain). Quaternary International 93/94, 13-18.

Giralt, S., Burjachs, F., Roca, J.R., Julià, R., 1999. Late Glacial to Early Holocene environmental adjustmente in the Mediterranean semi-arid zone of the Salines playa-lakes (Alacante, Spain). Journal of Paleolimmology 21, 449-460.

Gómez-Lobo, A. 1993. Historia de la vegetación durante los últimos 15.000 años en los Picos de Urbión (Soria) en base al análisis polínico. Ph.D. Thesis, Facultad de Ciencias, Universidad de Alcalá, 173 pp. 
Gómez-Orellana, L., 2002. El último ciclo glaciar interglaciar en el Litoral del NW Ibérico: Dinámica climática y paisajística. Ph.D. Thesis, Escola Politécnica Superior, Universidade de Santiago de Compostela.

Gómez-Orellana, L., Ramil-Rego, P., Muñoz-Sobrino, C., 1998. Una nueva secuencia polínica y cronológica para el depósito Pleistoceno de Mougás (NW de la Peninsula Iberica). Revue Paleobiologie 17(1), 35-47.

Gómez-Orellana, L., Ramil-Rego, P., Muñoz-Sobrino, C., Rodríguez-Guitián, M., 2001. Análisis polínico y cronológico de los depósitos pleistocenos de Moucide (Cangas de Foz, Lugo) y Río Boó (Muras, Lugo). In: Fombella Blanco-Castro, M.A., Fernández González, D., Valencia Barrera, R.M. (Eds.), Palinología: Diversidad y Aplicaciones. pp. 153-160.

Gómez-Orellana, L., Ramil-Rego, P., Muñoz-Sobrino, C., 2007. The Würm in NW Iberia, a pollen record fron Area Longa (Galicia). Quaternary Research 67, 438-452.

González-Sampériz, P., 2004. Evolución paleoambiental del sector central de la cuenca del Ebro durante el Pleistoceno Superior y Holoceno. Instituto Pirenaico de Ecología-CSIC, Zaragoza. 210 pp.

González-Sampériz, P., Montes, L., Utrilla, P., 2003. Pollen in hyena coprolites from Gabasa Cave (northern Spain). Review of Palaeobotany and Palynology 126, 7-15.

González-Sampériz, P., Valero-Garcés, B.L., Carrión, J.S., Peña-Monné, J.L., García-Ruiz, J.M., Martí-Bono, C., 2005. Glacial and Lateglacial vegetation in northeastern Spain: New data and a review. Quaternary International 140/141, 4-20.

González-Sampériz, P., Valero-Garcés, B.L., Moreno, A., Jalut, G., García-Ruiz, J.M., Martí-Bono, C., Delgado-Huertas, A., Navas, A., Otto, T., Dedoubat, J.J., 2006. Climate variability in the Spanish Pyrenees during the last 30,000 yr revealed by the El Portalet sequence. Quaternary Research 66(1), 38-52. 
González-Sampériz, P., Valero-Garcés, B.L., Moreno, A., Morellón, M., Navas, A., Machín, J., Delgado-Huertas, A., 2008. Vegetation changes and hydrological fluctuations in the Central Ebro Basin (NE Spain) since the Late Glacial period: Saline lake records. Palaeogeography, Palaeoclimatology, Palaeoecology 259: 157-181.

Grau, E., 1990. El uso de la Madera en yacimientos valencianos de la Edad del Bronce a época visigoda. Datos etnobotánicos y reconstrucción ecológica según la Antracología. PhD University of Valencia.

Head, M.J., Gibbard, P., 2005. Early-Middle Pleistocene transitions: an overview and recommendation for the defining boundary. In: Head, M.J., Gibbard, E.L. (Eds.), EarlyMiddle Pleistocene Transitions: The Land-Ocean Evidence. Geological Society, London, Special Publications 247, 1-18.

Hewitt, G., 1999. Post-glacial recolonization of European biota. Biological Journal of Linnean Society $68,87-112$.

Hooghiemstra, H., Stalling, H., Agwu, Ch.O.C., Dupont, L.M., 1992. Vegetational and climatic changes at the northern fringe of the Sahara 250,000-5000 years BP: evidence from 4 marine pollen records located between Portugal and the Canary Islands. Review of Palaeobotany and Palynology 74, 1-53.

Howell, F.C., Butzer, K.W., Freeman, L.G., Klein, R.G., 1995. Observations on the Acheulian occupation site of Ambrona (Soria province) with particular reference to recent investigation (1980-1983) and the Early occupation. Jahrbuch des Römisch-Germanischen Zentralmuseum Mainz 38, 33-81.

Huntley, B., Birks, H., 1983. An atlas of past and present pollen maps for Europe: 0-13.000 years ago. Cambridge: Cambridge University Press. 
Isturitz, M.J., Sánchez-Goñi, M.F., 1990. Investigaciones palinológicas en la prehistoria vasca. Munibe 42, 277-285.

Jalut, G., Sacchi, D., Vernet, J.L., 1975. Mise en evidence d'un refuge tardiglaciaire à moyenne altitude sur le versant nord-oriental des Pyrénnées (Belvis, alt. 960m, Aude). C. R. Acad. Sci. Paris t. 280, Série D, 1781-1784.

Joannin, S., 2007. Changements climatiques en Mediterranée à la transition Pléistocène inférieurmoyan: pollens, isotopes stable et cyclostratigraphie. Ph.D. Thesis, Université Claude Bernard-Lyon 1, 249 pp.

Julià, R., 1977. Nuevos datos sobre la posición cronoestratigráfica de las materiales cuaternarios de la cuenca lacustre de Banyoles-Besalú (Girona). Acta Geológica Hispánica 12, 55-59.

Julià, R., 1980. La conca lacustre de Banyoles-Besalú. Monografies del Centre d'Estudis Comarcals de Banyoles, Girona.

Julià, R., Suc, J.P., 1980. Analyse pollinique des dépôts lacustres du Pléistocène inférieur de Banyoles (Banõlas, site de Bòbila Ordis-Espagne): un élément nouveau dans la reconstitution de l'histoire paléoclimatique des régions méditerranéennes d'Europe occidentale. Géobios 13, 5-19.

Klotz, S., Guiot, J., Mosbrugger, V., 2003. Continental European Eemian and early Würmian climate evolution: comparing signals using different quantitative reconstruction approaches based on pollen. Global and Planetary Change 36(4), 277-294.

Lebreton, V., Renault-Miskovsky, J., Carrión, J.S., Dupré, M., 2006. Etude palynologique du remplissage de la grote du Boquete de Zafarraya. In: Barroso, C., de Limley, H. (Eds.), La Grotte Boquete de Zafarraya, Monographie Institut de Pléontologie Humaine, Junta de Andalucia. Consejería de Cultura. Málaga, pp. 629-660. 
Leigh Mascarelli, A., 2009. Quaternary geologist win timescale vote. Redefinition rescues oncethreatened terminology from extinction. Nature vol. 459, 624 .

Leroi-Gourhan, A., 1966. Analisis polínico de la cueva del Otero: excavaciones en la cueva del Otero (Santander). In: González Echegaray, J., García Guinea, M.A., Begines Ramírez, A. (Eds.), Excavaciones arqueológicas en España. Cueva del Otero. Ministerio de Educación. Madrid, pp: 83-85.

Leroi-Gourhan, A., 1971a. Analisis polínico de cueva Morín. Cueva Morín, excavaciones 19661968. Patronato de las cuevas prehistóricas de la provincia de Santander, 359-364.

Leroi-Gourhan, A., 1971b. La fin du tardiglaciaire et les industries préhistoriques (PyrénéesCantabres). Munibe 2(3): 249-254.

Leroi-Gourhan, A., 1980. Yacimiento de la cueva del Pendo. Análisis polínico. In: González Echegaray, J., (ed.) El yacimiento de la cueva de El Pendo (exc. 1953-57). Bibliotheca Praehistorica Hispana, CSIC, Madrid, 265-266.

Leroi-Gourhan, A., 1986. The palynology of La Riera cave. In: Strauss, L.G., Clark, G.A. (eds.): La Riera Cave. Arizona State Unversity, Anthropological Papers 36, 59-64.

Leroy, S.A.G., 1987. Analyse palynologique de deux nouvelles sections du Pléistocène Inférieur de Banyoles (Catalogne). Actas del VI Simposio de Palinologia, APLE, Salamanca, pp. 303313.

Leroy, S.A.G., 1988. Image pollinique d'une steppe du Pliocène Supérieur à Bóbila Ordis, Banyoles (Catalogne). Institut Français de Pondichéry, Trav. Sec. Sci. Techn. 75, 197-207.

Leroy, S.A.G., 1990. Paléoclimats Plio-Pléistocènes en Catalogne et Languedoc d'après la palynologie de formations lacustres. Ph.D. Thesis, Université Catholique de Louvain, Faculté des Sciences. Belgique. 
Leroy, S.A.G., 1997. Climatic versus non climatic lake-level changes from a Plio-Pleistocene lacustrine complex of Catalonia (Spain): palynology of the Tres Pins sequences. Journal of Paleolimnology 17( 4), 347-367.

Leroy, S.A.G., 2007. Progress in palynology of the Gelasian-Calabrian Stages in Europe: ten messages. Revue de Micropaléontologie 50, 293-308.

Leroy, S.A.G., 2008. Vegetation cycles in a disturbed sequence around the Cobb-Mountain subchron in Catalonia. JoPI 40(3), 851-868.

Leroy, S.A.G., Arpe, K., 2007. Glacial refugia for summer-green trees in Europe and S-W Asia as proposed by ECHAM3 time-slice atmospheric model simulations. Journal of Biogeography $34,2115-2128$.

Leroy, S.A.G., Seret G., 1992. Duration and vegetation dynamic of the Nogaret Interglacial (1.9 Ma, S. France). Tentative correlation with stage 75. In: Kukla G. and Went E. (eds), Start of a Glacial, Proceedings of the Mallorca NATO ARW, NATO ASI Series I, 3: 113-125, Springer Verlag, Heidelberg.

Leroy, S.A.G., Giralt, S., Francus, P., Seret, G., 1996. The high-sensitivity of the palynological record in the Vico Maar lacustrine sequence (Latium, Italy) highlights the climatic gradient through Europe for the last 90 ka. Quaternary Science Reviews 15, 189-201.

Leroy, S.A.G., Magnin, F., Coen, M., Agustí, J., Løvlie, R., 1997. Late Calabrian vegetation succession, gastropod and ostracod assemblage changes during isotopic Stage 35 from a multidisciplinary study of lake 1 of Bòbila Ordis (Catalonia, N-E Spain). extended abstract. Inter-INQUA colloquium, Ankara, Turkey, 25-28.

Leroy, S.A.G., Julià, R., Agustí, J., Løvlie, R., Coen, M., Magnin, F., Seret, G., Suc, J.P., 2001. The Early Pleistocene lacustrine sequences of Tres Pins and Bòbila Ordis (Catalonia). Fieldguide, 3rd SEWG workshop, Girona, Terra Nostra 2, 63-77. 
Lisiecki, L.E., Raymo, M.E., 2007. Plio-Pleistocene climate evolution: trends and ransitions in glacial cycle dynamics. Quaternary Science Reviews 26, 56-69.

López-García, P., 1981. Análisis polínico del yacimiento de Los Azules (Cangas de Onís, Oviedo). Botanica Macaronesica, 8/9, 243-248.

López-Merino, L., 2009. Paleoambiente y antropización en Asturias durante el Holoceno. Ph.D. Thesis. Universidad Autónoma de Madrid, Madrid.

López-Merino, L.; López-Sáez, J.A.; Ruiz Zapata, M.B., Gil García, M.J., 2008. Reconstructing the history of beech (Fagus sylvatica L.) in the north-western Iberian Range (Spain): From Late-Glacial refugia to the Holocene anthropic-induced forests. Review of Palaeobotany and Palynology, 152: 58-65.

López-Sáez, J.A., López-García, P., 1999. Rasgos paleoambientales de la transición TardiglaciarHoloceno (16-7.5 BP) en el Mediterráneo ibérico, de Levante a Andalucía. In:Ferrer, C., Blázquez, A.M. (Eds.), Geoarqueologia i Quaternary litoral. Memorial M.P.Fumanal. Pp: $139-152$.

López-Sáez, J.A., López-García, P., Cortés, M. 2007. Paleovegetación del Cuaternario reciente: estudio arqueopalinológico. In: Cortés (Ed.), Cueva Bajoncillo (Torremolinos). Secuencia cronocultural y paleoambiental del Cuaternario reciente en la Bahía de Málaga. Centro de Ediciones de la Diputación Provincial de Málaga, 139-156.

Løvlie, R., Leroy, S.A.G., 1995. Magnetostratigraphy of Early Pleistocene Banyoles paleolake carbonate sediments from Catalonia, NE-Spain: evidence for relocation of the Cobb Mountain sub-chron. Quaternary Science Reviews 14(5), 473-486.

Magri, D., 2008. Patterns of post-glacial spread and the extent of glacial refugia of European beech (Fagus sylvatica) (Special Issue). Journal of Biogeography 35, 450-463. 
Magri, D., Parra, I., 2002. Late Quaternary western Mediterranean pollen records and African winds. Earth and Planetary Science Letters 200(3/4), 401-408.

Maldonado, J., 1994. Evolución Tardiglaciar y Holocena de los macizos del Noreste Peninsular. Ph.D. Thesis, Escuela Técnica Superior de Ingenieros de Montes, Universidad politécnica de Madrid, 171 pp.

Martín-Arroyo, T., 1998. Paleoclimatología y Paleoambiente durante el Pleistoceno Medio y Superior en el valle del Tajo. Ph.D. Thesis. Universidad de Alcalá de Henares, 173 pp.

Martín-Arroyo, T., Ruiz-Zapata, B., Pérez-González, A., 1995. Reconstrucción paleoclimática y paleoambiental durante el Pleistoceno medio en el valle del río Tajo: primeros datos polínicos. In: Aleixandre, T., Pérez-González, A. (eds.). Construcción de Paleoambientes y cambios climáticos durante el Cuaternario. Monografías, 3, Centro de Ciencias Medioambientales, CSIC, Madrid, pp. 347-361.

Martín-Arroyo, T., Ruiz-Zapata, B., Pérez Gónzalez, A., 1996a. Paleoambiente en el valle del río Tajo durante el Pleistoceno superior: primeros datos polínicos. In: Ramil-Rego, P., Fernández Rodríguez, C., Rodríguez Guitián, M. (Eds.), Biogeografía PleistocenaHolocena de la Península Ibérica. Xunta de Galicia. Santiago de Compostela, pp. 73-86.

Martín-Arroyo, T., Ruiz-Zapata, B., Valdeolmillos, A., Benito, G. de, 1996b. Reconstrucción de la vegetación durante el cuaternario reciente en El Puente del Arzobispo (Toledo, España): primeros datos polínicos. In: Ruiz-Zapata, B. (Eds.), Estudios palinológicos.XI Simposio de Palinología (A.P.L.E.), Universidad de Alcalá, Alcalá de Henares, pp. 91-94.

Martín-Arroyo, T., Ruiz-Zapata, B., Pérez-González, A., Valdeolmillos, A., Dorado Valiño, M., Benito, G., Gil-García, M.J., 1999. Paleoclima y paleoambiente durante el Pleistoceno Superior y Tardiglaciar en la región central peninsular. In: Pallí Buxó, L., Roqué Pau, C., 
(eds.). Avances en el estudio del Cuaternario español: Secuencias, Indicadores, Paleoambientes y Evolución de Procesos. Girona, pp. 317-324.

Mateus, J.E., Queiroz, P.F., 1993. Os estudos da vegetação quaternária em Portugal; contextos, balanço de resultados, perspectivas. In: Carvalho, G.S., Ferreira, A.B., Senna-Martínez, J.C., coords. O Quaternário em Portugal. Balanço e perspectivas. Lisboa, Associação Portuguesa para o Estudo do Quaternário, pp. 105-131.

McKeever, M.H. 1984. Comparative palynological studies of two lake sites in western Ireland and northwestern Spain. Thesis. Trinity College, Dublin, Ireland.

Médail, F., Diadema, K., 2009. Glacial refugia influence plant diversity patterns in the Mediterranean Basin. Journal of Biogeography. DOI: 10.1111/ j.1365-2699. 2008.02051. x.

Menéndez-Amor, J., Florschütz, F., 1959. Algunas noticias sobre el ambiente en que vivió el hombre durante el gran interglaciar en dos zonas de ambas Castillas. Estudios Geológicos 15: $277-285$.

Menéndez-Amor, J., Flörschutz, F., 1963. Sur les éléments stepiques dans la végétation cuaternaire del'Espagne. Bol. Real. Soc. Esp. Hist. Nat.(G.) 61, 121-133.

Montserrat, J., 1992. Evolución glaciar y postglaciar del clima y la vegetación en la vertiente sur del Pirineo: Estudio palinológico. Monografías del Instituto Pirenaico de Ecología 6, Instituto Pirenaico de Ecología, CSIC, Zaragoza.

Moreno, A., Cacho, I., Canals, M., Grimalt, J.O., Sánchez-Goñi, M.F., Shackleton, N.J., Sierro, F., 2005. Links between marine and atmospheric processes oscillating on a millennial timescale. A multi-proxy study of the last $50.000 \mathrm{yr}$ from the Alboran Sea (Western Mediterranean Sea). Quaternary Science Reviews 24, 1623-1636.

Moreno, A., López-Merino, L., Leira, M., Marco Barba, J., González-Sampériz, P., Valero-Garcés, B.L., López-Sáez, J.A., Santos, L., Mata, P., Ito, E., 2009. Revealing Holocene 
environmental history from the multiproxy record of a mountain lake (Lago Enol, $\mathrm{N}$ Iberian Peninsula). Journal of Paleolimnology, in press.

Munuera, M., Carrión, J.S., 1991. Palinología de un depósito arqueológico en el sureste ibérico semiárido: Cueva del Algarrobo (Mazarrón, Murcia). Cuaternario y Geomorfología 5, 107118.

Muñoz-Sobrino, C., 2001. Cambio climático y dinámica del paisaje en las montañas del noroeste de la Península Ibérica. Ph.D. Thesis, Escola Politécnica Superior, Universidade de Santiago de Compostela.

Muñoz-Sobrino, C., Ramil-Rego, P., Delibes de Castro, G., Rojo, M., 1996. Datos paleobotánicos sobre la turbera de La Piedra (Páramo de Tozo, Burgos). In: Ramil-Rego, P., FernándezRodriguez, C., Rodríguez Guitian, M.A. (Eds.), Biogeografía Pleistocena-Holocena de la Península Ibérica, Xunta de Galicia, Santiago de Compostela, pp. 149-162.

Muñoz-Sobrino, C., Ramil-Rego, P., Rodríguez Guitian, M.A., 1997. Upland vegetation in the North-West Iberian Peninsula after the last glaciation: forest history and deforestation dynamics. Vegetation History and Archaeobotany 6, 215-233.

Muñoz-Sobrino, C., Ramil-Rego, P., Rodríguez Guitian, M.A., 2001. Vegetation in the mountains of northwest Iberian during the last glacial-interglacial transition. Vegetation History and Archaeobotany 10, 7-21.

Muñoz-Sobrino, C., Ramil-Rego, P., Gómez-Orellana, L., 2004. Vegetation of the Lago Sanabria area (NW Iberia) since the end of the Pleistocene: a palaeoecological reconstruction on the basis of two new pollen sequences. Vegetation History and Archaeobotany 13, 1-22.

Muñoz-Sobrino, C., Ramil-Rego, P., Gómez-Orellana, L., 2007. Late Würm and early Holocene in the mountains of northwest lberia: biostratigraphy, chronology and tree colonization. Vegetation History and Archaeobotany 16, 223-240. 
Naughton, F., Sánchez-Goñi, M.F., Desprat, S., Turon, J.L., Duprat, J., Malaizé, B., Joli, C., Cortijo, E., Drago, T., Freitas, M.C., 2007. Present day and past (last 25000 years) marine pollen signal off western Iberia. Marine Micropaleontology 62, 91-114.

Olalde, M., Herrán, A., Espinel, S., Goicoechea, P., 2002. White oaks phylogeography in the Iberian Peninsula. Forest Ecology and Management 156, 89-102.

Ortiz, J.E., Delgado, A., Julià, R., Lucini, M., Llamas, F.J., Reyes, E., Valle, M., 2004. The palaeoenvironmental and palaeohydrological evolution of Padul Peat Bog (Granada, Spain) over one millon years. Organic Geochemistry 35, 1243-1260.

Pantaleón-Cano, J., YII, E.I., Pérez-Obiols, R., Roure, J.M., 2003. Palynological evidence for vegetational history in semi-arid areas of the western Mediterranean (Almeria, Spain). The Holocene 13(1), 109-119.

Parès, J.M., Pérez-González, A., 1999. Magnetochronology and stratigraphy at Gran Dolina section, Atapuerca (Burgos, Spain). Journal of Human Evolution 37, 325-342

Parra, I., 1994. Quantification des précipitations à partir des spectres polliniques actuels et fossiles: du Tardiglaciaire à l'Holocène Supérieur de la côte méditerranéene espagnole. Ph.D. Thesis, Université de Montpellier, Francia.

Peñalba, M.C., 1994. The history of the Holocene vegetation in northern Spain from pollen analysis. Journal of Ecology 82, 815-832.

Peñalba, M.C., Maurice, A., Guiot, J., Duplessy, J.C., de Beaulieu, J.L., 1997. Termination of the last glaciation in the Iberian Peninsula Inferred from the Pollen Sequence of Quintanar de la Sierra. Quaternary Research 48, 205-214.

Pérez-Collazos, E., Catalán, P., 2007. Genetic diversity analysis and conservation implications for the Iberian threatened populations of the irano-turanian relict Krascheninnikovia ceratoides (Chenopodiaceae). Biological Journal of the Linnean Society 92 (3), 419-429. 
Pérez-González, A., Santonja, M., Gallardo, J., Aleixandre, T., Sesé, C., Soto, E., Mora, R., Villa, P., 1997. Los yacimientos pleistocenos de Torralba y Ambrona y sus relaciones con la evolución geomorfológica del Polje de Conquezuela (Soria). Geogaceta 21, 175-178.

Pérez-Obiol, R., 1988. Histoire tardiglaciaire et holocène de la végétation de la région volcanique d'Olot (NE Péninsule Ibérique). Pollen et Spores 30(2), 189-202.

Pérez-Obiol, R., Julià, R. 1992. The pollen sequence of Banyoles (Catalonia): vegetation and climate history of the last 30,000 years. 8th International Palynological Congress. Abstracts. Aix-en-Provence, p. 114.

Pérez-Obiol, R., Julià, R., 1994. Climatic change on the Iberian peninsula recorded in a 30,000 yr pollen record from lake Banyoles. Quaternary Research 41, 91-98.

Pérez-Obiol, R., Roure, J.M., Mallarach, J.M., 1986. Study of climatic changes during the recent quaternary in the northeastern iberian peninsula on the basis of pollen analysis. In:López Vera, F. (Eds.), Quaternary Climate in Western Mediterranean. Universidad Autónoma de Madrid. Madrid, pp: 297-305.

Petit, R., Brewer, S., Bordac, S., Burg, K., Chedaddi, R., Coart, E., Cottrell, J., Csaikl, U., van Dam, B., Deans, J., Espinel, S., Fineschi, S., Finkeldey, R., Glaz, I., Goicoechea, P., Jensen, J., Koning, A., Lowe, A., Madsen, S., Matyas, G., Munro, R., Popescu, F., Slade, D., Tabbener, H., de Vries, S., Ziegenhagen, B., de Beaulieu, J., Kremer, A., 2002. Identification of refugia and post-glacial colonisation routes of European white oaks based on chloroplast DNA and fossil pollen evidence. Forest Ecology and Management 156, 4974.

Pons, A., Reille, M., 1988. The Holocene and Late Pleistocene pollen record from Padul (Granada, Spain): a new study. Palaeogeography, Palaeoclimatology, Palaeoecology 66, 243-263. 
Postigo, J.M., 2003. Contribución al conocimiento de la vegetación pleistocena de la Península Ibérica. Estudio paleobotánico de macrorrestos vegetales fósiles. Ph. D. Thesis, Universidad Autónoma de Madrid, Facultad de Ciencias.

Postigo, J.M., Burjachs, F., Gómez Manzanaque, F., Morla, C., 2007. A palaeoecological interpretation of the Early-middle Pleistocene Cal Guardiola site (Terrasa, Barcelona, NE Spain) from the comparative study of wood and pollen samples. Review of Palaeobotany and Palynology 146, 247-264.

Postigo, J.M., Gómez Manzaneque, F., Morla, C., 2008. Survival and long-term maintenance of tertiary trees in the lberian Peninsula during the Pleistocene: first record of Aesculus L. (Hippocastanaceae) in Spain. Vegetation History and Archaeobotany 17, 351-364.

Postigo, J.M., Barrón, E., Gómez Manzaneque, F., Morla, C., 2009. Floristic changes in the lberian Peninsula (SW Europe) during the Cenozoic. Journal of Biogeography. DOI: 10.1111/j.1365-2699.2009.02142.x

Postigo, J.M., Barrón, E., García, S., Morales, C., Morla, C., 2010. Quaternary extinctions of tree flora in the Iberian Peninsula. Review of Palaeobotany and Palynology, in press.

Provan, J., Bennet, K.D., 2008. Phylogeographic insights to cryptic glacial refugia. Trends in Ecology and Evolution 23 (10), 564-571.

Pulido, F., Valladares, F., Calleja, J.A., Moreno, G., González-Bornay, G., 2008. Tertiary relict trees in a Mediterranean climate: abiotic constraints on the eprsistence of Prunus lusitanica at the eroding edge of its range. Journal of Biogeography 35, 1425-1435.

Ramil-Rego, P., Aira Rodríguez, M.J., Alonso Mattias, F., 1993a. Caracterización climática y vegetacional de la Serra de Geres (Portugal) durante el Tardiglaciar y el Holoceno: análisis polínico de a Lagoa do Marinho. Actas $3^{\text {a }}$ Reunión del Cuaternario Ibérico, pp. 85-92. 
Ramil-Rego, P., Taboada Castro, M.T., Aira Rodríguez, M.J., 1993b. Estudio palinológico y factores de formación de la turbera de Gañidoira (Lugo, España). In: Fumanal, M.P., Bernabeu, J. (Eds.), Estudios sobre Cuaternario, medios sedimentarios, cambios ambientales, hábitat humano. Universitat de València, València, pp. 191-197.

Ramil-Rego, P., Gómez-Orellana, L., 1996. Dinámica climática y biogeográfica del área litoralsublitoral de Galicia durante el Pleistoceno Superior-Holoceno. In: Ramil-Rego, P., Fernández-Rodríguez, C., Rodríguez Guitián, M.A. (Eds.), Biogeografía PleistocenaHolocena de la Península Ibérica. Xunta de Galicia. Santiago de Compostela, pp. 43-72.

Ramil-Rego, P., Muñoz-Sobrino, C., Rodríguez-Guitián, M., Gómez-Orellana, L., 1998. Differences in the vegetation of the North Iberian Peninsula during the last 16,000 years. Plant Ecology $138,41-62$.

Ramil-Rego, P., Rodríguez-Guitián, M., Muñoz-Sobrino, C., 1998. Sclerophyllous vegetation dynamics in the north of the Iberian peninsula during the last 16,000 years. Global Ecology and Biogeography Letters 7, 335-351.

Raymo, M.E., Oppo, D.W., Flower, B.P., Hodell, D.A., McManus, J.F., Venz, K.A., Kleiven, K.F. \& Mclntyre, K., 2004. Stability of North Atlantic water masses in face of pronounced climate variability during the Pleistocene. Palaeoceanography, 19, PA2008, DOI:10.1029/2003PA000921.

Rio, D., Sprovieri, R., Castradori, D., Di Stefano, E., 1998. The Gelasian Stage (Upper Pliocene): A new unit of the global standard chronostratigraphic scale. Episodes 21/2, 82-87.

Rivas Martínez, S., 2007. Mapa de series, geoseries y geopermaseries de vegetación de España. Memoria del mapa de la vegetación potencial de España. Itineraria Geobotanica 17, 1-436.

Rodríguez-Ariza, M.O., 1996. Análisis antracológicos de yacimientos neolíticos de Andalucía. Rubricatum: revista del Museu de Gavà 1, 73-83. 
Rodríguez-Ariza, M.O., 2005. Análisis antracológico del yacimiento Solutrense de Cueva Ambrosio (Vélez, Almería). In: Sanchidrián, J.L., Márquez, A.M., Fullola, J.M. (Eds.), La Cuenca Mediterránea durante el Paleolítico Superior 38000-10000 años. IV Simposio de Prehistoria Cueva de Nerja. Málaga, pp. 226-233.

Rodríguez-Sánchez, F., Pérez Barrales, R., Ojeda, F., Vargas, P., Arroyo, J. 2008. The Strait of Gibraltar as a meeting pot for plant biodiversity. Quaternary Science Reviews 27, 21002117.

Roiron, P., 1983. Nouvelle étude de la macroflore plio-pléistocène de Crespià (Catalogne, Espagne). Geobios 16(6), 687-715.

Roiron, P., 1992. Flores, végétations et climats du Néogène méditerranéen: apports de macroflores du Sud de la France et du Nord-Est de l'Espagne. Thèse d'Etat Sciences, Univ. Montpellier II, 296 pp.

Ros Mora, M.T., 1987. Anàlisi antracològica de la cova de l'Arbreda. Cypsela 6, 67-71.

Roucoux, K.H., Shackleton, N.J., de Abreu, L., 2001. Combined Marine Proxy and Pollen Analyses Reveal Rapid Iberian Vegetation Response to North Atlantic Millennial-Scale Climate Oscillations. Quaternary Research 56, 128-132.

Roucoux, K.H., de Abreu, L., Shackleton, N.J., Tzedakis, P.C., 2005. The response of NW Iberian vegetation to North Atlantic climate oscillations during the last 65 kyr. Quaternary Science Reviews 24, 1637-1653.

Roucoux, K.H., Tzedakis, P.C., de Abreu, L., Shackleton, N.J., 2006. Climate and vegetation changes 180,000 to 345,000 years ago recorded in a deep-sea core off Portugal. Earth and Planetary Science Letters 249, 307-325. 
Roucoux, K.H., Tzedakis, P.C., de Abreu, L., Shakleton, N.J., 2007. Fine-tuning the land-ocean correlation for the Late Middle Pleistocene of Southern Europe. In: Sirocko, F., Claussen, M., Sánchez-Goñi, M.F. (Eds.), The Climate of Past Interglacials 7, 359-373.

Ruiz-Alonso, M., 2004. Análisis antracológico del yacimiento de Irikaitz (Zestoa, Gipuzkoa). Resultados preliminares, en I Congreso Peninsular de Estudiantes de Prehistoria. Tarragona, pp. 361-366.

Ruiz-Zapata, M.B., Gil-García, M.J., 2005. Los neandertalescantábricos: su paisaje vegetal. In: Montes Barquin, R., Lasheras Corruchaga, J.A. (Eds.), Neandertales cantábricos: estado de la cuestión. Monografía 20. Museo Nacional y centro de Investigación de Altamira, pp. $275-284$

Ruiz-Zapata, M.B., Pérez-González, A., Dorado Valiño, M., Valdeolmillos Rodríguez, A., Bustamante Gutiérrez, I., Gil-García, M.J., 2000. Caracterización climática de las etapas áridas del Pleistoceno Superior en la Región Central Peninsular. Geotemas 1(4), 273-278.

Ruiz-Zapata, M.B., Gil-García, M.J., Vegas, J., Dorado, M., Valdeolmillos, A., Pérez González, A., 2003a. Registro palinológico de los eventos Heinrich $(\mathrm{H} 1$ y H2) en la secuencia de la Laguna Grande (Sierra de Neila, Sistema Ibérico, España). In: Flor, G. (Ed.), Actas de la XI Reunión Nacional del Cuaternario. Oviedo, pp. 293-300.

Ruiz-Zapata, M.B., Pérez Gonzalez, A., Santonja, M., Gil-García, M.J., Dorado Valiño, M., Valdeolmillos, A., 2003b. Vegetación mesopleistocena del poljé de Conquezuela (Soria). Polen 13, 5-17.

Ruiz-Zapata, M.B., Dorado, M., Valdeolmillos, A., Gil-García, M.J., Martín-Arroyo, T., Pérez González, A., 2004. Registro paleoambiental y paleoclimático del Pleistoceno medio y superior en depósitos fluviales del Valle del río Tajo (Toledo). In: Miscelanea en Homenaje 
a Emiliano Aguirre, vol. II: Paleontología, Museo Arqueológico Regional, Alcalá de Henares, 507-518.

Rull, V., 2009. Microrefugia. Journal of Biogeography 36, 481-484.

Sainz-Ollero, H., Moreno, J.C., 2002. Flora vascular endémica española. In: Pineda, F.D., de

Miguel, J.M., Casado, M.A., Montalvo, J. (Eds.), La diversidad biológica de España. Pretince Hall - CYTED, pp. 175-195.

Sánchez-Goñi, M.F. 1996. Les changements climatiques du Paléolithique Supérieur. Enquête sur le rapport entre Paléoclimatologie et Préhistoire. Zephyrus 49, 3-36.

Sánchez-Goñi, M.F., 1988. A propos de la présence du pollen de Castanea et de Juglans dans les sédiments archéologiques würmiens anciens du Pays Basque espagnol Inst. Fr. de Pondichéry tv. sec. sci. tech. 25, 73-82.

Sánchez-Goñi, M.F., 1992. Analyse palynologique de sites préhistoriques de Pays Basque: prémiers résultats pour les grottes de Lezetxiki et Urtiaga. In: The late Quaternary in the western Pyrenean region. Universidad del País Vasco, pp. 207-233.

Sánchez-Goñi, M.F., 1993. De la taphonomie pollinique à la reconstitution de l'environnement. L'exemple de la région cantabrique. BAR International Series 586, Oxford, 207 pp.

Sánchez-Goñi, M.F., Eynaud, F., Turon, J.L., Shackleton, N.J. 1999. High resolution palynological record of the Iberian margin: direct land-sea correlation for the Last Interglacial complex. Earth and Planetary Science Letters 171, 123-137.

Sánchez-Goñi, M.F., Cacho, I., Turon, J.L., Guiot, J., Sierro, F.J., Peypouquet, J.P., Grimalt, J.O., Shackleton, N.J., 2002. Synchroneity between marine and terrestrial responses to millennial scale climatic variability during the last glacial period in the Mediterranean region. Climate Dynamics 19, 95-105. 
Sánchez-Goñi, M.F., Loutre, M.F., Crucifix, M., Peyron, O., Santos, L., Duprat, J., Malaizé, B., Turon, J.-L., Peypouquet, J.-P., 2005. Increasing vegetation and climate gradient in Western Europe over the Last Glacial Inception (122-110 ka): data-model comparison. Earth Planet. Sci. Lett. 231, 111-130.

Sánchez-Goñi, M.F., Landais, A., Fletcher, W.J., Naughton, F., Desprat, S., Duprat, J., 2008. Contrasting impacts of Dansgaard- Oeschger events over a western European latitudinal transect modulated by orbital parameters. Quaternary Science Reviews 27, 1136-1151.

Santonja, M., Pérez-González, A., Villa, P., Sesé, C., Soto, E., Mora, R., Eisenman, V., Dupré, M., 2000. El yacimiento paleolítico de Cuesta de la Bajada (Teruel) y la ocupación humana de la zona oriental de la Península Ibérica en el Pleistoceno medio. In: Scripta in Honorem a Enrique Llobregat. Inst. Alicantino de Cultura Juan Gil-Albert, Alicante, pp. 79-101.

Scott, G., Gibert, L., 2009. The oldest hand-axes in Europe. Nature 461, 82-85.

Schulte, L., Julià, R., Burjachs, F., Hilgers, A., 2008. Middle Pleistocene to Holocene geochronology of the River Aguas terrace sequence (Iberian peninsula): Fluvial response to Mediterranean environmental change. Geomorphology 98, 13-33.

Shackleton, N.J., Hall, M.A., Pate, D., 1995. Pliocene stable isotope stratigraphy of Site 846. Proceedings of the Ocean Drilling Program Scientific Results 138, 337-355.

Stauffer, B., Blunier, T., Datlenbach, A., Indermuhle, A., Schwander, J., Stocker, T.F., Tschumi, J., Chappelaz, J., Raynaud, D., Hammer, C.U., Clausen, H.B., 1998. Atmospheric CO2 concentration and millennial-scale climate change during the last glacial period. Nature 392, 59-62.

Soler, J.A., Dupré, M., Ferrer, C., González-Sampériz, P., Grau, E., Máñez, S., Roca de Togores, C., 1999. Cova d'en Pardo, Planes, Alicante: primeros resultados de una investigación 
pluridisciplinar en un yacimiento prehistórico. In: Fumanal, M.P. (Eds.), Geoarqueología quaternari litoral: memorial. Universidad de Valencia, Valencia, pp 269-282.

Stevenson, A. C., 1984. Studies in the vegetational history of S.W. Spain. III. Palynological investigations at El Asperillo, Huelva. Journal of Biogeography 11, 527-551.

Stewart, J.R., Dalén, L., 2008. Is the glacial refugium concept relevant for northern species? A comment on Pruett and Winker 2005. Climatic Change 86, 19-22.

Suc, J.P., 1980. Contribution à la connaissance du Pliocène et du Pléistocène inférieur des régions méditerranéennes d'Europe occidentale par l'analyse palynologique des dépôts du Languedoc-Roussillon (sud de la France) et de la Catalogne (nord-est de l'Espagne). Thése de Doctorat en Sciences Naturelles, Montpellier, 198 pp.

Suc, J.P., Cravatte, J., 1982. Etude palynologique du Pliocène de Catalogne (Nord-Est de l'Espagne). Paléobiologie Continentale 12 (1),1-31.

Suc, J.P., Popescu, S.M., 2005. Pollen records and climatic cycles in the North Mediterranean region since 2.7 Ma. In: Head, M.J., Gibbard, P.L. (Eds.), Early-Middle Pleistocene Transitions: The Land-Ocean Evidence. Geological Society, 247, 147-158.

Svenning, J.C., 2003. Deterministic Plio-Pleistocene extinctions in the European cool-temperate tree flora. Ecology Letters 6, 646-653.

Taberlet, P., Fumagalli, L., Wust-Saucy, A., Cossons, J., 1998. Comparative phylogeography and post-glacial colonisation routes in Europe. Molecular Ecology 7, 453-464.

Teixeira, C., 1943. Sôbre a existência do Género Sabal no Pliocénico portugués. Bull. Soc. Port. Sc .Nat. 28, 135-139.

Tzedakis, P.C., 1994. Vegetation change through glacial-interglacial cycles: a long pollen sequence perspective. Philosophical transactions of the Royal Society of London B342, 403-432. 
Tzedakis, P.C., 2007. Seven ambiguities in the mediterranean palaeoenvironmental narrative. Quaternary Science Reviews 26, 2042-2066.

Tzedakis, P.C., 2009. Museums and cradles of Mediterranean biodiversity. Journal of Biogeography, doi:10.1111/j.1365-2699.2009.02123.x.

Tzedakis, P., Lawson, I., Frogley, M., Hewitt, G., Preece, R., 2002. Buffered tree population changes in a Quaternary refugium: evolutionary implications. Science 297, 2044-2047.

Tzedakis, P.C., McManus, J., Hooghiemstra, H., Oppo, D., Wijmstra, T.A., 2003. Comparison of changes in vegetation in northeast Greece with records of climate variability on orbital and suborbital frequencies over the last 450,000 years. Earth and Planetary Science Letters $212,197-212$.

Uzquiano, P., 1988. Analyse anthracologique du Tossal de la Roca (Paléolithique Superieurfinal/Epipaléolithique, province d'Alicante, Espagne). Révue PACT, 22.IV.1. Proceedings of Congress Bois et Archéologie. In: Hackens, T., Munaut, A., Till, C. (Eds.), Louvain-laNeuve, pp. 209-217.

Uzquiano, P., 1992a. L'homme et le bois au Paléolithique en Region Cantabrique, Espagne. Les exemples d'Altamira et El Buxu. Les charbons de bois, les anciens écosystèmes et le rôle de l'homme. In: Vernet, J.L. (Ed.), Bull. Soc. Bot. Fr. Actualités Botaniques, 2/3/4, 361-372. Paris.

Uzquiano, P., 1992b. The Lateglacial-Postglacial transition in the Cantabrian Cordillera (Asturias and Cantabria, Spain) based on charcoal analysis. Palaios 7, 540-547.

Uzquiano, P., 1995. La dispparition de Picea à la fin du Pléistocène supérieur en Région Cantabrique d'après l'anthracoanalyse : déterminisme climatique et anthropique. Comptes Rendus à l'Académie des Sciences, Paris, t. 321, série lla : 545-551. 
Uzquiano, P., 1998. La végétation cantabrique de 13000 à 9000 BP d'après l'analyse anthracologique. Habitats et ramassages de bois dans un milieu changeant. Proceedings of the XIIIth UISPP Congress, vol. I (A.B.A.C.O. (Ed.). Forli, Italia, pp. 477-482.

Uzquiano, P., 2005. El Registro Antracológico durante la transición Musteriense-Paleolítico Superior Inicial en la Región Cantábrica: vegetación, paleoambiente y modos de vida en torno al fuego. In: Montes, R., Lasheras, J.A., (eds.). Neandertales cantábricos, estado de la cuestión. Museo de Altamira, Santander. Monografías, 20: pp. 255-274.

Uzquiano, P., 2007. La Antracología de las unidades musterienses y del Auriñaciense de Transición de la cueva de El Castillo (1984-2001). Dinámica de la vegetación y de gestión del combustible. Miscelánea en homenaje a Victoria Cabrera vol. 1. In: Maillo, J.M., Baquedano, E. (Eds.), Museo Arqueológico Regional, Alcalá de Henares. Zona Arqueológica 7, 132-143.

Uzquiano, P., 2008. Domestic fires and vegetation cover among Neanderthalians and Anatomic Modern Human groups (>53-30Kyrs. BP) in the Cantabrian region (Cantabria, Northern Spain). In: Fiorentino, G., Magri, D. (Eds.), Charcoal from the Past: cultural and palaeoenvironmental implications. Proceedings of the IIIrd International Meeting of Anthracology. Cavallino-Lecce (Italy). 28 th June-1st July 2004. British Archaeological Reports 1807, pp. 273-285.

Uzquiano, P., (in press). Balance de resultados antracoanalíticos en la Región Cantábrica durante el Solutrense superior y el Magdaleniense. $1^{\text {a }}$ Mesa Redonda sobre el Paleolítico Superior Cantábrico. Gestión del territorio y Movilidad de los grupos cazadores-recolectores durante el Tardiglaciar. San Román de Candamo, Asturias. Accepted in Monografías del Instituto Internacional de Investigaciones Prehistóricas de Cantabria. Universidad de Cantabria. Santander (in press). 
Uzquiano, P., Arbizu, M., Arsuaga, J.L., Adan, G., Aranburu, A., Iriarte, E., 2008. Datos paleoflorísticos en la cuenca media del Nalón entre 40-32 Ka. BP: antracoanálisis de la cueva del Conde (Santo Adriano, Asturias). Actas XII Reunión Nacional de Cuaternario AEQUA, Ávila. In: Baena, J., Lario, J. (eds.). Cuaternario y Geomorfología, 22: 121-133.

Valdeolmillos, A., 2005. Registro paleoclimático y paleoambiental de los últimos 350.000 años en el Parque Nacional de las Tablas de Daimiel (Ciudad Real). Ph.D. Thesis. Universidad de Alcalá, Alcalá de Henares, 281 pp.

Valdeolmillos, A., Dorado Valiño, M., Ruiz-Zapata, M.B., Bardají, T., Bustamante, I., 2003. Paleoclimatic record of the Last Glacial Cycle at Las Tablas de Daimiel National Park (Southern Iberian Meseta, Spain). In: Ruiz-Zapata, M.B., Dorado Valiño, M., Valdeolmillos, A., Gil-García, M.J., Bardají, T., de Bustamante, I., Martínez Mendizábal, I. (Eds.), Quaternary climatic changes and environmental crises in the Mediterranean Region. Alcalá de Henares, pp. 222-228.

Valero-Garcés, B.L., Delgado-Huertas, A., Navas, A., Machin, J., González-Sampériz, P., Kelts, K., 2000a. Quaternary palaeohydrological evolution of a playa lake: Salada Mediana, central Ebro Basin, Spain. Sedimentology 47, 1135-1156.

Valero-Garcés, B.L., González-Sampériz, P., Delgado-Huertas, A., Navas, A., Machin, J., Kelts, K., 2000b. Late glacial and Late Holocene environmental and vegetational change in Salada Mediana, central Ebro Basin, Spain. Quaternary International 73-4, 29-46.

Valero-Garcés, B.L., González-Sampériz, P., Navas, A., Machin, J., Delgado-Huertas, A., PeñaMonne, J.L., Sancho-Marcen, C., Stevenson, T., Davis, B., 2004. Paleohydrological fluctuations and steppe vegetation during the last glacial maximum in the central Ebro valley (NE Spain). Quaternary International 122, 43-55. 
van Campo, M., 1969. Végétation Würmienne en France. Données bibliographiques. Hypothèse. Etudes Françaises sur le Quaternaire. VIllè Congrès International de I'INQUA. Paris. Offprint.

van der Knaap, W.O., Van Leeuwen, J.F.N., 1997. Late Glacial and early Holocene vegetation succession, altitudinal vegetation zonation, and climatic change in the Serra da Estrela, Portugal. Review of Palaeobotany and Palynology 97, 239-285.

Vegas, J., Pérez-González, A., Ruiz-Zapata, M.B., López, M.J., Pollard, J.P., López-Sáez, J.A., Dorado, M., Gil-García, M.J., Valdeolmillos, A., Mclntosh, G., Osete, M.L., Uzquiano, P., Delgado, A., 2001. Environmental events occurred during the Holocene in Laguna Grande and Laguna del Hornillo lacustrine records. Northwestern of the Iberian Range (Spain). In: Nostra, Terra (Ed.), Intercomparison among the Mediterranean Holocene lacustrine sequences: Temporal and spatial extension of environmental short events. Schriften der Alfred-Wegener-Stiftung 2001/2. Institute of Earth Science (Jaume Almera), CSIC, Girona, pp. 57-60.

Vegas, J., Ruiz-Zapata, M.B., Ortiz, J.E., Galán, J., Torres, T., García-Cortés, A., Pérez-González, A., Gallardo-Millán, J.L., 2008. Identificación de las principales fases áridas del Pleistoceno superior en el registro sedimentario lacustre del mar de Fuentillejo (Campo de Calatrava). Geotemas 10, 1467-1470.

Vera, J.A., 2004. Geología de España. Ed. Instituto Geológico y Minero. Madrid, 884 pp.

Vernet, J.L., 1997. L’homme et la forêt mediterranéenne de la Préhistoire à nos jours. Paris, ed. Errance, $247 \mathrm{pp}$.

Vernet, J.L., Terral, J.F. 2006. Les charbons de bois des niveux mousteriens et protoaurignaciens de la Grotte du Boquete de Zafarraya. In : Barroso, C., de Lumley, H. (Eds.), La Grotte du Boquete de Zafarraya- tome-II. Junta de Andalucía, Consejería de Cultura, pp. 661-673 
Villalta, J.F., Vicente, J., 1972. Una flora del cuaternario antiguo en las cercanías de Crespià. Acta Geológica Hispánica VII, 120-128.

Von Engelbrechten, S., 1998. Late-glacial and Holocene vegetation and environmental history of the Sierra de Urbión, North-Central Spain. Ph.D. Thesis, University of Dublin, Dublin.

Walker, M. J., Gibert, J., Sánchez, F., Lombardi, A. V.,Serrano, I., Eastham, A., Ribot, F., Arribas, A., Cuenca, A., Sánchez-Cabeza, J-A., García-Orellana, J., Gibert, L., Albaladejo, S. \& Andreu, J. A., 1998. Two SE Spanish middle palaeolithic remains: Sima de las Palomas del Cabezo Gordo and Cueva Negra del Estrecho del Río Quípar (Murcia province). Internet Archaeology 5, <http://intarch.ac.uk/journal/issue5/walker_index.html>

Walker, M. J., López-Sáez, J. A., San Nicolás, M., Carrion, J. S., Mancheño, M. A., Schewenninger, J-L, López-Martínez, M., López-Jiménez, A., San Nicolás del Toro, M., Hills, M. D., Walkling, T., 2006. Cueva Negra del Estrecho del Río Quípar (Murcia, southeast Spain): An Acheulian and Lavalloiso-Mousteriod assemblage of Paleolithic artifacts excavated in a Late Cromerian faunal context with hominid skeletal remains. Eurasian Prehistory 4, 3-43.

Willis, K., 1994. The vegetational history of the Balkans. Quaternary Science Reviews 13, 769-788.

YII, E.I., Pérez-Obiol, R., 1992. Instalación de los bosques deducida a partir del análisis polínico de un sondeo marino del Delta del Ebro. Orsis 7, 21-30.

YII, E.I, Carrión, J.S., Pantaleón, J., Dupré, M., La Roca, N., Roure, J.M., Pérez-Obiols, R., 2003. Palinología del Cuaternario reciente en la Laguna de Villena (Alicante). Anales de Biología $25,65-72$.

Zazo, C., Dabrio, C., González, A., Sierro, F., YIl, E.I., Goy, J.L., Luque, L., Panataleón-Cano, J., Soler, V., Roure, J.M., Lario, J., Hoyos, M., Borja, F., 1999. The record of the latter glacial 
and interglacial periods in the Guadalquivir marshlands (Mari López drilling, S.W. Spain). Geogaceta 26, 119-122.

Zbyszewski, G. 1958. Le Quaternaire de Portugal. Boletim da Sociedade Geològica de Portugal, $12,1-227$

Zilhão, J., Marks, A.E., Ferring, C.R., Bicho, N.F., Figueiral, I., 1995. The Upper Paleolithic of the Rio Maior Basin (Portugal). Preliminary results of a 1987-1993 portuguese-american research project. Trabalhos de Antropologia e Etnologia 35(4), 69-82.

Ziska, L.H., Caulfield, F.A., 2000. Rising $\mathrm{CO} 2$ and pollen production of common ragweed (Ambrosia artemisiifolia), a known allergy-inducing species: implications for public health. Australian Journal of Plant Physiology 27, 893-898. 


\section{Figure captions}

Figure 1: Map of the bioclimatic zones of Iberia with the main Pleistocene sites cited in the text. Correspondence names to numbers are included in Table 1.

Figure 2: Ages of the main Early Pleistocene sites in Iberia. Limits of the Early Pleistocene (beginning of the Quaternary): Gelasian (Late Pliocene) and Calabrian periods (most of the Early Pleistocene). Ages of the limits after Gibbard and van Kolfschoten (2004) and Head and Gibbard (2005). Some marine isotopic stages (MIS) are given in the third and fourth column. CM: Cobb Mountain subchron. M: Matuyama chron. Garraf 1 sequence after Suc and Cravatte (1982), and Suc and Popescu (2005); Crespià site after Roiron (1992); Tres Pins after Leroy (1997); Bòbila Ordis after Leroy (2008); Cal Guardiola after Postigo et al. (2007); ODP site 976 after Combourieu-Nebout et al. (1999); Atapuerca after Burjachs (2001) and Berger et al. (2008).

Figure 3: Selected taxa from the pollen diagram of the Late Pliocene site of Garraf (modified from Fauquette et al., 1998a)

Figure 4: Selected pollen taxa from the pollen histogram of Bòbila Ordis, lake 2 (modified from Leroy, 1988). The sequence of lake 2 (sequence BOC4) represents a very open landscape. It is not directly dated. However stratigraphically it is between lake 1 (BOIV, Leroy, 2008) and lake 3 (BOIl and BOIII, Leroy, 1987).

Figure 5: Pollen diagram of the Middle Pleistocene site of Atapuerca (modified from García-Antón and Sainz-Ollero, 1991).

Figure 6: Selected taxa from the pollen diagram of the Middle Pleistocene sequence of marine core MD01-2443 (modified from Roucoux et al., 2006).

Figure 7: Chronological distribution of the main continental full glacial lberian sites of the Late Pleistocene (MIS 4, MIS 3 and MIS 2).

Figure 8: Pollen diagram of the Würm phase of the Late Pleistocene site of Area Longa (modified from Gómez-Orellana et al., 2007) 
Figure 9: Anthracological synthesis of the Late Pleistocene data from Cantabrian and Mediterranean regions. Cantabrian Region: Pinus and Betula are the most representative taxa along MIS 4 and MIS 3 besides Sorbus aria that are important in MIS 3. Juniperus, Salix and Heathland shrubs (Cytisus, Ulex, Erica) are characteristic during MIS 2 before the Lateglacial. Betula reappears since this event. Karstic shrubs consist on spiny deciduous shrubs (Sambucus, Crataegus, Prunus spp., Hippophae rhamnoides) and Mediterranean shrubland (Rhamnus alaternus, Phillyrea sp., Arbutus unedo) and Meso-thermophilous trees group is composed by deciduous Quercus, Castanea, Fagus, Corylus and Fraxinus. Quercus ilex Pleistocene occurrences are noticed, as well as Abies and Picea. Mediterranean Region: Pinus, shrubs (Rhamnus cathartica, R. alaternus, Prunus spp., Buxus, Phillyrea sp.) and deciduous trees (deciduous Quercus, Corylus, Fagus, Sorbus sp., Acer spp., Betula) are the most representative taxa during the MIS 3 in NE Iberia. Pinus-Juniperus alternations are the main vegetation trend in S/SE Iberia during the MIS 2. Besides Olea, deciduous trees (deciduous Quercus, Q. faginea type, Fraxinus ornus, F. oxyphylla, Acer spp., Salix-Populus) and a more varied shrub vegetation cover (Crataegus, Sambucus, Prunus spp., Rhamnus alaternus, Phillyrea sp., Pistacia lentiscus, P. terebinthus, Buxus, Cistus sp., Rosmarinus, Fabaceae, Viscum, Ephedra and Chenopodiaceae) are recorded. Quercus ilex-coccifera is always present but in small amounts.

Figure 10: Selected taxa of the pollen diagram from the Late Pleistocene site of Abric Romaní (modified from Burjachs and Julià, 1994).

Figure 11: Comparison pollen diagram of Late Pleistocene sequence from Padul peatbog and Carihuela cave (modified from Fernández et al., 2007).

Figure 12: Selected taxa of the pollen diagram from the Late Pleistocene sequence of marine core MD95-2042 (modified from Sánchez-Goñi et al., 1999).

Figure 13: Full glacial (MIS 4 to MIS 2) distribution of: i) Mesothermophilous taxa (deciduous Quercus, Corylus, Alnus, Tilia, Fagus); ii) Mesothermophilous taxa including 
Sclerophyllous elements (evergreen Quercus, Olea, Pistacia, Phillyrea, Myrtus, Buxus, Rhamnus); and iii) Mesothermophilous taxa including sclerophyllous elements and IberoMaghrebian scrub (Maytenus, Periploca, Ziziphus, Withania, Lycium, Calicotome). 


\section{Tables}

Table 1: List of Pleistocene Iberian sites, location, type of data (pollen, charcoal), chronology and references.

Table 2: List of Late Pliocene-Early Pleistocene sites with altitude, number and type of samples, type of floral remains preserved, ages, and source of information ("${ }^{*}$ pre-cyclostratigraphy ages).

Table 3: Occurrence of some taxa that have disappeared in the Quaternary in Late Pliocene-Early Pleistocene sites. In order of possible disappearance, with the earliest to the left (sp: species not precised; *: morphology unknown to the palynologist; always maximum amounts noted). 